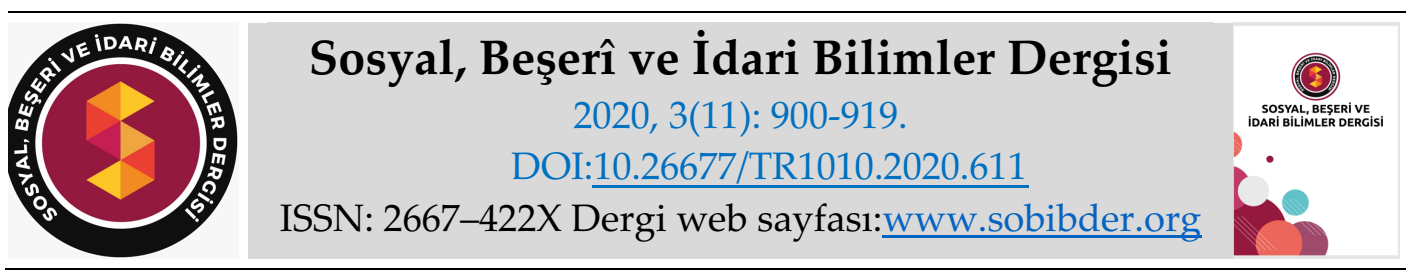

$\underline{\text { ARASTTIRMA MAKALESI }}$

\title{
İstanbul Eyüpsultan, Cafer Paşa Tekkesi Kültür ve Sanat Merkezi Projesi*
}

Prof. Dr. Sedat BAYRAKAL, Uşak Üniversitesi, Fen Edebiyat Fakültesi, Uşak, e-posta: sedat.bayrakal@hotmail.com

ORCID: https://orcid.org/0000-0002-3727-1424

\section{Öz}

İslam dünyası ve sanatının inanç örgüsü içinde şekillenen planlarıyla varlıklarını sürdüren tekkeler farklı şekillerde biçimlendirilmiştir. Mescid, tekke, tevhidhane, haremlik, selamlık, türbe-hazire, mutfak, hela gibi birimleri bünyesinde barındıran ve şekilden çok öze yönelen tekke binaları, işlevleri gereği külliye planlaması gösterirler. Bu anlamda İstanbul-Eyüpsultan'daki önemli bir eser olan Cafer Paşa Tekkesi, aynı aksta bulunan Yahyazade, Özbekler, Afife Hatun tekkeleriyle birlikte, döneminin önemli tarikat alanlarından birisine konumlandırılmıştır. Türbedeki kitabesine göre Cafer Paşa tarafından 1585 yılında veya bu yıla yakın tarihte yapıldığı anlaşılan Tekke, revaklı Osmanlı medreseleri ve bununla bağlantılı, ortak avlu etrafında sıralanan cami-medrese binalarından ilham almış görünmektedir. Osmanlı döneminde çokça örneğiyle karşılaşılan ve ortak açık avluyu kullanan tekkeler, bir tarikat yapısının faaliyetlerini daha teşkilatlı sürdürmesi bakımından fonksiyonel görünmektedir. Açık avlunun kuzey, güney ve doğu olmak üzere üç kenarını "u" şeklinde kuşatan medrese/tekke hücreleri, güney kanadın batı ucuna avluya taşacak şekilde yerleştirilen mescid/dershane/tevhidhane ve külliyenin batı kesimine yerleştirilen dikdörtgen türbe, çevre duvarı içine alınmıştır. Bugünlerde türbenin güneyinde kalan avlu ile tekke avlusunda sergi alanı; dershane ve hücrelerde çeşitli kültürel faaliyetlerin hayata geçirileceği düzenlemelere yönelik proje geliştirilmiştir. Bu makale, uygulamaya konulacak projenin, 1. derecede korunması gerekli kültür varlığı ile ilişkisini sağlıklı kılacak yani tarihi esere en az müdahalede, bir başka deyişle, plan ve cephelerde değişikliğe gidilmeyecek boyutta müdahale için tavsiye ve rehber niteliği taşıması amacıyla kaleme alınmıştır.

* Söz konusu çalışma, araştırmanın odağını oluşturan külliyenin yerinde incelenmesine dayanarak yazılan Sanat Tarihi içerikli araştırmanın yayına dönüştürülmüş hâlidir. Bu kapsamda, yardım ve katkılarından dolayı Sayın Ahmet ALATAŞ’a şükranlarımı sunarım. Ayrıca böylesine değerli bir projeyi hayata geçirmek isteyen Eyüpsultan Belediyesi yetkililerine de yürekten teşekkür ederim.

Anahtar Kelimeler: Cafer Paşa Tekkesi, Cafer Paşa Türbesi, Tekke, Kültür ve Sanat Projesi, Eyüpsultan.

Makale Gönderme Tarihi: 26.08.2020

Makale Kabul Tarihi: 02.11.2020

\footnotetext{
Önerilen Atıf:

Bayrakal, S. (2020). İstanbul Eyüpsultan, Cafer Paşa Tekkesi Kültür ve Sanat Merkezi Projesi, Sosyal, Beşeri ve İdari Bilimler Dergisi, 3(11): 900-919.

(C) 2020 Sosyal, Beşerî ve İdari Bilimler Dergisi.
} 


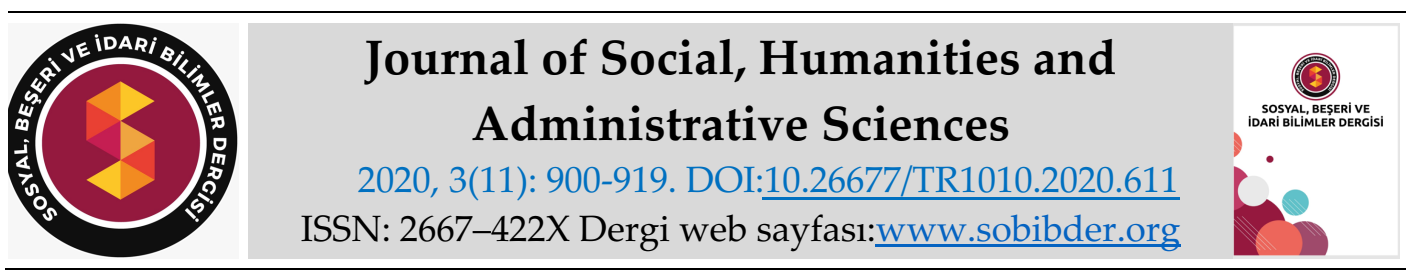

RESEARCH PAPER

\title{
İstanbul Eyüpsultan, Cafer Pasha Dervish Lodge Culture and Art Center Project
}

Prof. Dr. Sedat BAYRAKAL, Uşak University, Faculty of Arts and Sciences, Uşak, e-mail: sedat.bayrakal@hotmail.com

ORCID: https://orcid.org/0000-0002-3727-1424

\begin{abstract}
The dervish lodges, which sustain their existence with the plans shaped within the belief pattern of the Islamic world and art, have been shaped in different ways. Dervish lodge buildings, which include units such as masjid, dervish lodge, monotheism hall, a place reserved for women, a place reserved for men, mausoleum-hazire, kitchen, toilet, and focus more on the essence, display complex planning due to their functions. In this sense, Cafer Pasha Dervish Lodge, which is an important work in İstanbul-Eyüpsultan, is located in one of the important sect areas of its period, together with the Yahyazade, Özbekler, Afife Hatun lodges on the same axis. According to the inscription on the mausoleum, it is understood that the dervish lodge was built by Cafer Pasha in 1585 or close to this year, seems to have been inspired by the Ottoman madrasas with porticoes and the associated mosque-madrasa buildings lined up around the shared courtyard. Dervish lodges, which were encountered with many examples in the Ottoman period and used the shared open courtyard, seem functional in terms of maintaining the activities of a sect structure more organized. The madrasah/lodge cells that surround the three sides of the open courtyard in the shape of a "u", the masjid/classroom/monotheism hall at the west end of the south side extended to the courtyard, and the rectangular tomb located in the western part of the complex are enclosed in the surrounding wall. Today, a project has been developed to regulate various cultural activities in the courtyard to the south of the tomb and the exhibition area in the courtyard of the lodge, classrooms, and cells. This article has been written in order to make the relationship of the project to be implemented healthy with the cultural property that needs to be preserved in the first degree, that is, to serve as a recommendation and guide for the least intervention to the historical artifact, in other words, intervention at a scale that will not change the plans and facades.
\end{abstract}

Keywords: Cafer Pasha Dervish Lodge, Cafer Pasha Tomb, Dervish Lodge, Culture and Art Project, Eyüpsultan.

Received: 26.08 .2020

Accepted: 02.11.2020

\section{Suggested Citation:}

Bayrakal, S. (2020). İstanbul Eyüpsultan, Cafer Pasha Dervish Lodge Culture and Art Center Project, Journal of Social, Humanities and Administrative Sciences, 3(11): 900-919.

(C) 2020 Sosyal, Beşerî ve İdari Bilimler Dergisi. 


\section{Gíriş}

Eyüpsultan ilçesi, Merkez Mahallesi, 52 ada, 74 parselde, batıdan Kalenderhane Cad. güneyden Hz. Halid Bulvarı ile çevrilen arsaya konumlandırılan Cafer Paşa Külliyesi türbe, medrese/tekke ve medreseye bağlı mescid/tevhidhaneden oluşmaktadır ve çevre duvarı içine alınmıştır (Şek. 1, Foto. 1). Külliyenin batısında yer alan türbeyi kuzey ve güneyden içine alan kuşatma duvarı, doğuya yönelerek ortadaki avluyu geçer, güneyden mescid duvarına yaslanır, kuzeyde ise medresenin avlusunu sınırlandırır. Evliya Çelebi'nin "... orta yol canibindedir" (Evliya Çelebi, 1314:408) şeklindeki tarifine göre, bugünkü Kalenderhane Caddesi'nin, o dönemde "Orta Yol" adıyla anıldığı öğrenilmektedir. Hadîkatü'l-Cevâmi'de, Cafer Paşa Medresesi yakınındaki Kızıl Mescid'in aynı adla anılan mahallede bulunduğu belirtildiğinden, bugünkü Merkez Mahalle'nin, Ayvansarâyî'nin incelediği dönemde Kızıl Mescid Mah. adıyla bilindiği anlaşılmaktadır (Ayvansarâyî, 1281:279). Günümüzde Kızıl Mescid sadece muhit adı olarak varlığını sürdürmektedir.

Tekke, dinî anıtlar bakımından odak noktası sayılabilecek, aynı zamanda Kalenderhane Caddesi aksındaki Afife Hatun, Özbekler ve Yahyazade tekkeleriyle de tarikat yapılarının önemli eserlerini barındıran Eyüpsultan'ın merkezindedir (Şek. 2).

Başlangıçta, Cafer Paşa tarafından halvetî tekkesi olarak yapılan eserin, daha sonra 18. yüzyılın üçüncü çeyreğinde, muhtemelen Hacı Yahya Efendi adında bir Kâdirî şeyhi tarafından canlandırıldığı, daha sonra tekrar sahipsiz kalan tekkeye bu sefer, Sa'diyye Tarîkatı'ndan Mehmed Salih Sırrı Efendi'nin şeyhlik yaptı̆̆ kaydedilmiş, özellikle son dönemde her cuma günü Mevlid okunduğu ve âyin (mukâbele) yapıldığı kaydedilmiştir. Bu bilgilere göre sırasıyla Halvetiyye, Kadiriyye ve Sa'diyye tarîkatlarının tekkesi konumuna gelmiş ve bu nedenle Hacı Yahya-i Kadirî, Kırımî Hacı Hafız, Kırımî, Salih Sırrı Efendi Tekkesi isimleriyle de anılır olmuştur (Tanman, 1990:37; Çetin, 2012:179).

1 Muharrem 1199 / 14 Kasım 1784 tarihli 1. Abdülhamid dönemine tarihlenen bir belgede, hükümdarın bir geleneğe göre, her yılın 1 muharreminde tarikat erbabının hayır dualarını kazanmak amacıyla dağıtacağı hediyeler dolayısıyla, İstanbul ve civarındaki tekke, zaviye ve hankahların tesbît edildiği bir müfredat defterinde, "Etrâf-1 Hâric-i Sûr" başlı̆̆ı altındaki listede, Eyüp'te Cafer Paşa Türbesi'nde Hacı Yahya-yı Kâdirî Tekyesi de verilmiştir (Çetin, 1981:587). Bu bilgi, tekkenin 18. yüzyılın üçüncü çeyreğinde, bir Kâdirî Tekkesi olduğu bilgisini ve türbenin varlığını teyit etmektedir.

Türbenin, güney girişindeki kitabesine göre, Kanuni Sultan Süleyman Dönemi vezirlerinden Cafer Paşa tarafından yaptırıldığı öğrenilmektedir. Külliyede sadece bu kitabe bulunmaktadır. Medrese ve ona ait mescitte ise herhangi bir yazıt yoktur. Vaktiyle Kız Kuran Kursu olarak değerlendirilen medrese, bugün Eyüpsultan Belediyesi'ne ait "Cafer Paşa Medresesi Kültür Sanat Merkezi" olarak hizmet vermektedir. 1970 yılında Vakıflar Genel Müdürlüğü tarafından medrese-tekke kanadının onarıldığı, türbenin ise yarım bırakıldığı belirtilmektedir (Tanman, 1990:37).

Külliyenin genel planı şöyle teşekkül etmiştir: Medrese ve türbe blokları doğu-batı ekseninde uzanmış, ancak medrese, türbenin bir miktar kuzeydoğusuna düşmüştür (Şek. 1). Külliyeyi, harpuştalı yüksek ihata duvarı sınırlandırmaktadır. Çevre duvarında moloz ve kabayonu taşlarla birlikte tuğla örgü kullanılmıştır. Giriş, batıya yerleştirilen iki açıklıktan sağlanmaktadır (Foto. 2). Bu açıklıklar aynı zamanda türbenin batı duvarının güney ve kuzey aksına denk düşmektedir. Türbenin güneybatısındaki giriş açıklığı, yapının güneyindeki verev hacme geçit vermektedir. Bu giriş, tıpkı kuzeydeki açıklık gibi, düzgün kesme küfeki taşından basık kemerlidir. Kuzeydeki diğer açıklık, türbenin kuzeyindeki dar koridor vasıtasıyla avluya ve medreseye ulaşımı 
sağlamaktadır. İki giriş arasında, türbenin caddeye bakan iki katlı cephesi dikkati çekmektedir. Bu cephe, yola baktığından diğer cephelerden farklı olarak düzgün kesme taşlarla örülmüştür.

Türbenin güney duvarının doğuya doğru devamında, türbenin güneyindeki avlu ile orta birimdeki avluya geçiş imkânı veren tali bir giriş açıklığı daha bulunmaktadır. Türbe duvarlarındaki almaşık duvar örgüsü düzensizdir: sayıları 1 ile 3 arasında değişen tuğla sıralarının arasına düzgün kesme küfeki taşlar yerleştirilmiştir. Tali girişin sonradan açıldığını düşünüyoruz. Zira türbeye yaslanan girişin almaşık örgüdeki tuğla sıraları, türbedeki tuğla sıralarını karşılamadığı gibi, türbe ile söz konusu giriş arasındaki bitişme çizgisi bu saptamayı kanitlamaktadır.

Külliye eserlerinde, düzenli ve birbirini takip eden duvar örgüsü yerine malzeme farklılı̆̆ göze çarpmaktadır. Herkesin kolaylıkla görebildiği ve Kalenderhane Caddesine bakan iki katlı batı cephesinde, düzgün küfeki taşlar, alt sıra pencere sövelerinde mermer kullanılmışken; içte, avlu ve mekân duvarlarında sayıları değişkenlik gösteren tuğla ve taş almaşıklığı kullanılmıştır.

\section{TÜRBE}

Külliyenin giriş yönündeki eseri olan bina, doğu-batı yönünde uzanan, içten içe yaklaşık $14.5 \times 8.5$ m ölçülerindeki dikdörtgen bir hacimden ibarettir (Şek. 3). Bugün üzeri açı olan türbenin vaktiyle ahşap çatıyla örtülü olup olmadığı tartışmalıdır. Ekibiyle birlikte 1997 ve 1998 yıllarında türbede kazı yapan rahmetli Örcün Barışta, Süheyl Ünver tarafından 29.03.1966 yılında yapılan bir çizimde, yapının üzerinin kırma çatı ile örtülü olarak gösterildiğini, fakat kesin hüküm vermenin olanaksız olduğunu ve iki yıllık kazı çalışmalarının sonucuna göre üst örtüsünün olmadığı görüşünün hâkim olduğunu belirtmektedir (Barışta, 2000:255, 257). O günlerde olduğu gibi bugün de beden duvarlarının üst kesimlerinde çatıya ait iz yoktur. Belki Sayın Ünver'in çizimine göre o tarihte ahşap çatılı olduğunu söyleyebiliriz, ancak yapıldığı dönem için kesin hüküm vermek zordur. Bugün söz konusu ize rastlanmayışı, ahşap çatıyı hatırlattığı kadar, üzerinin açık olabileceğini de düşündürür.

Türbeyle ilgili bir diğer tartışma, yapının bir türbe olarak mı yapıldığı yoksa bir başka binanın türbeye mi dönüştürüldüğüdür. Sayın Barışta, doğu duvarındaki nişlere ve üst seviyedeki büyük ve bol sayıdaki penceresiyle, 16. yüzyılın alışılageldik türbelerinden farklı bir türbe görüntüsü çizdiğini belirtse de çok sayıda onarıma tabi tutulan türbenin hepimizi yanıltma payı olduğu hesaba katılmalıdır. Sayın Barışta'nın tartışmaya açtığı bir başka husus, 1584 tarihli mezar taşlarının, türbenin inşa tarihinden (1585) daha önceye tarihlenmesine dayanılarak, türbeye sonradan yerleştirilmiş olabileceği ve binanın sonradan türbeye dönüştürülmüş olabileceğidir (Barışta, 2000:255). Belki de bugünkü türbenin bulunduğu alan küçük bir hazire olarak tasarlanmıştı, daha sonra buradaki ehl-i tarikat mezar taşlarının sınırları belli bir mekânla korunma ve vurgulanmaları düşünülmüştü. Şüphesiz, bu savları kanıtlayacak verilere sahip değiliz. M. Baha Tanman, türbenin kısmen tevhidhane olarak kullanıldığını belirtmektedir (Tanman, 1990:37; Tanman, 1994a:368).

Bir başka husus, Cafer Paşa Tekkesi'nin tevhidhane kısmının nerede olduğuyla ilgilidir. Son zamanlarda, mescidin aynı zamanda tevhidhane olarak kullanıldığı bilinse de önceleri külliyede bir başka mekânın tevhidhane olarak değerlendirildiği ifade edilmiştir. A. Bilgin Turnalı, tekke listelerinde ve Mehmed Salih Sırrı Efendi'ye ait vakfiye özetinde Cafer Paşa Türbesi'nden ve buradaki bir hücreden bahsedilmesine dayanarak, tekkenin türbe bitişiğindeki bir odadan ibaret olduğu görüşünü savunmaktadır (Turnalı, 1992:555). Ancak buradaki "tekke" kavramından ne kastedildiği anlaşılamamıştır. Belki de "tevhidhane" binasından söz edilmiştir, aksi taktirde, bilindiği üzere tekke, daha fazla sayıda ve kapsamlı birimlerin oluşturduğu bir tarikat kuruludur. 
1 metre kalınlığa yaklaşan türbe duvarları, çevre duvarından daha kalındır. Türbeye doğrudan girilememekte, öncelikle güneybatıya açlan ve Kalenderhane Caddesi'ne bakan girişin ardından avluya, daha sonra güney cephesi ortasına açılan türbe kapısına ulaşılmaktadır (Foto. 3). Basık kemerli güney girişi, sivri kemerli çökertme içine alınmış, basık kemerin üzerine mermer kitabe panosu yerleştirilmiştir. Güney girişi, içten de özenli bir şekilde işlenmiştir. Giriş aralığı dilimli kaş kemerle örtülmüş, alınlık yatay dikdörtgen pano şeklinde düzenlenmiştir. Türbeye girişi sağlayan bir diğer açıklık, kuzey cephesinin ortasında, güneydekiyle aynı eksende yer alan daha küçük boyutlardaki açıklıktan ibarettir (Foto. 4). Söz konusu açıklğı̆n sonradan kapı olarak kullanıldığı anlaşılsa da başlangıçta pencere olduğunu düşünüyoruz. Kaldı ki türbenin güney, doğu ve batı duvarlarının alt sıra pencereleri, kuzeydeki açıklıkla aynı düzene ve boyutlara sahiptir. Bugün açıklığın içe bakan kesimine demir parmaklıklı kanat takılmıştır. Söz konusu pencerenin, koridordan geçenlerin türbede yatanlara dua etmesi için açldığını zannediyoruz. Türbenin güneybatı ve güneydoğu köşeleri pahlanmış, güneydoğudaki pahlı kesim mukarnaslarla geçilmiştir.

Türbenin güney kapısı üzerindeki şair Nihâdî́ye ait kitabe metninden, türbenin Cafer Paşa tarafından H. 993 / M. 1585 yılında yaptırıldığını öğreniyoruz (Foto. 5) (Mehmed Süreyya 1996: 1255)1. Tarih, kitabede rakamla verilmemiş, ebcede işaret edilmiştir². Beş beyitlik sülüs kitabe metninin transkripsiyonu şöyledir:

Eyledi Ḥażret-i Ca'fer Paşa / Ḥürmet-i merḳad-i evlād-ı kirām

Yapdı bu türbe-i mānend-i behişt / Hem-çū firdevs-i berīn dārü's-selām

Kim tilāvet ola Ḳur'ān-1 'aẓim / Ravża-i cennet-i ‘adn ola müdām

A‘ẓam-1 hayr-1 cemil eyledi kim / Ḩayırla yād ola tā rūz-ı ḳıyām

Vaṣf idüp didi Nihādī tārih̆ / Oldı bu türbe cinān gibi maḳām

İki katlı türbe, vaktiyle yirmi dört pencereyle aydınlatılmaktaydı. Batı cephesinde iki sıra hâlinde dörderden sekiz, doğu cephesinde üçerden altı, güney cepheye, beşi alt, dördü üst sırada dokuz, kuzey cepheye alt sırada bir pencere açılmıştır (Foto. 6-8). Güney cephesinin ortasında giriş, batısında iki, doğusunda üç alt sıra penceresi sıralanmaktadır. Bir başka deyişle, güney cephesinin ortasındaki giriş, alt sıra pencere düzenindeki simetriyi bozmaktadır. Alt sıradaki pencereler dikdörtgen şekilli, mermer söveli ve demir lokma parmaklıklı, üst sıradakiler sivri kemerlidir. Üst sıra pencerelerin muhtemelen döneminde, alçıdan içlik ve dışlıkları vardı.

İçte mezarlar, mihrap ve nişler dikkat çeken başlıca unsurlardır. Girişin sağında (batı) iki pencere arasında yedi kenarlı nişe sahip mihrap bulunmaktadır (Foto. 8). Taş ve tuğlalardan örülen mihrabın özellikle duvar örgüsünün üst yarısı düzensizdir. İkisi kuzey duvarında, diğer ikisi doğu duvarında olmak üzere dikdörtgen kesitli toplamda dört niş açılmıştır. Doğu duvarının kuzey kesimindeki nişten, en azından bu cephedeki nişlerin, altlı üstlü dilimli iki kaş kemerli mermer bölmeye sahip olduklarını anlıyoruz (Foto. 7). Türbedeki mezar taşlarından bazılarının başlıkları, bazılarının sanduka levhaları düşmüş ve doğu duvarındaki niş ve pencere içlerinde muhafaza edilmiştir. Sadeliğiyle ön plana çıkan türbede, Klasik Osmanlı üslubunun etkileri açıktır.

1 Şairin hayatı hakkında fazla bilgi bulunamamıştır. Sicill-i Osmanî'de, "Prizrenli'dir. III. Mehmed devri (1595-1603) şairlerindendir" şeklinde hayatı hakkında kısaca bilgi verilen şairin, türbe kitabesinin manzum şiirini yazan Nihâdî olduğunu zannediyoruz.

${ }^{2}$ Hesabı şöyle yapılmıştır: (Oldı: 51, bu: 8, türbe: 607, cinân: 104, gibi: 42, makam: 181=993) 
Türbenin içini dolduran mezarlar çeşitli form ve tiptedir. Bunlar sadece şahideli, kaideli ve sandukalı mezarlar olmak üzere üç tipte toplam yirmi sekiz adettir (Şek. 4, Foto. 9). 1997 ve ertesi yıl yapılan kazılar sonucu otuz altısı toprağa dikili elli bir mezar taşı saptandığına göre (Barışta, 2000:257), buradaki mezar taşlarının da hızla kaybolduğu söylenebilir. Mezar taşları Halvetî, Kadirî, Sa'dî tarîkatları mensuplarına ve yakınlarına aittir. Bazı mezar taşı kitabelerinin tanıtım ve okunuşları aşağıda verilmiştir.

Bunlardan ilk olarak türbenin banisi olan Cafer Paşa'nın mezar taşından bahsetmek istiyoruz. Lahit ya da sandukalı tip diyebileceğimiz mermer mezar, iki kademeli kaide üzerine oturtulmuştur (Şek. 5, Foto. 10-12). Dikdörtgen prizma şekilli gövdenin iki yanında simetrik konumlandırılmış yaprak bezemesi dikkati çekmektedir. Dikdörtgen gövdenin iki ucunda silindir şekilli birer şahide yükselmektedir. Bunlardan ayak taşı yazısız ve bezemesiz iken baş taşında, üstte "Ya Hayy", devamında "Kelime-i Tevhid", altta "Ya Kayyûm" yazmaktadır. Mezarın asıl yazısı, baş taşına değil gövdenin ön yüzüne yazılmıştır. Kitabede Ca'fer Paşa'nın $H$. 995 / M. 1587'de vefat ettiği yazmaktadır³. Şair Beyânî'ye ${ }^{4}$ ait sülüs hatlı kitabe metni şöyle okunmuştur:

Vezīir-i hāamis ol Ca'fer Paşa / Bu devr içre görüb üç pādişāhı

İdüp Sulțān Süleymān H̦ān'a ḩidmet / Selīm Hูān'a erince sürdü cāhı

Erişüp ba'dehū Sulțān Murād'a / Murādına erişmedi kemāhī

Ederken 'ālemi seyr ü temāşā / 'Adem-i iḳlīmine erişdi rāhı

Bir eksüklü Beyānī didi tārı̆h / Behişt ola maḳāmı yā illāhī sene 995

Tarih beytinde tamiyeli tarih kullanılmıştır. Son mısradaki kelimelerin ebced değerleri toplamı (behişt: 707, ola: 42, makamı: 191, ya: 11, ìlâhî: 46) 997 yapmaktadır. Bir önceki mısrada geçen "bir eksüklü" ibaresine göre 1 çıkarıldığında 996 rakamı elde ediliyor. Böylelikle kitabede rakamla verilen tarihten bir fazla sonuç çıkıyor. Tarihin hem ebced hem de rakamla verildiği bazı kitabelerde, burada olduğu gibi, yaklaşık sonuçlara ulaşıldığı zaman zaman rastlanan bir durumdur.

Türbe içinde medfun bulunan bir diğer tarikat üyesi Salih Sırrı Efendi'nin mezar taşı, bani Cafer Paşa mezarının hemen kuzeybatı çaprazında yer almaktadır (Foto. 13). Kapaklı ve şahideli tipteki mezarın ayak şahidesi, baş şahidesine göre kısa tutulmuştur. Sivri kemerli tepeliği yaprak ve çiçekler, gövdesini hurma ağacı motifi bezemektedir. Baş şahidesi, çapraz sarılmış başlı̆̆ı, talik hatlı kitabesiyle sunulmuştur. Kitabî bilgilere göre Sa'dî Tarikatı'ndan Hacı Salih Sırrı Efendi 3 Zilhicce 1285 / 17 Mart 1869 tarihinde vefat etmiştir. Kitabesinin transkripsiyonlu yazıllı̧ı şöyledir:

Hū

Ṭariḳat-1 ‘Alìyye-i Sa‘dìyyeden

Südlice Dergāh-1 Şerî́fi Şeyḩi

${ }^{3}$ Mehmed Süreyya, 1996 (2):381'de, bu tarihi 11 Safer 995 / 21 Ocak 1587 olarak vermektedir.

4 Şair Beyânî: Asıl adı Mustafa olan şair, Bulgaristan Rusçuk'ta doğdu. Şükrullah Halife'den talik icazeti alarak hattat olan Beyânî, hocasının tefsirini temize çekmesinin karşılığı olarak 20 akçe ile Kestel Medresesi'ne müderris tayin edildi. Daha sonra Havran kadısı oldu. Okmeydanı'ndaki Sofular Halvetî Tekkesi şeyhi Ekmeleddîn Efendi'ye bağlanarak tarîkata girdi ve resmî görevlerinden ayrıldı. Dîvânı olmayan şair, tarîkat çevrelerince sevilen bir şairdi. Beyânî H. 1006 / M. 1597 yılında vefat etti. 1592 yılında yazdığı Şuarâ Tezkiresi en önemli eseridir. (İsen, 1992:32). 
Süleymān Șıdḳı Efendi

merḥūmun ḩulefālarından ve bu maḳāma

Țariḳ-i Sa' dìyye üzre meşiḩat

vaż‘na muvaffaḳ olan merḥūm

magifūrun-leh eş-şeyḩ el-ḥāc Ṣāliḥ

Sırrı Efendi'nin rūḥuna Fātiḥa

Fī 3 z sene 1285

Türbe içinde yatanlardan bazıları aynı zamanda Tekke'ye şeyhlik yapmıştır. Yukarıda mezar taşı kitabelerini verdiğimiz Cafer Paşa ve Salih Sırrı Efendi'den başka Kırımî Hacı Süleyman Avni Efendi (Ö. 15 Şubat 1871), Kırımî Seyyid el-Hac Mustafa Efendi (Ö. 2 Temmuz 1878) türbe içinde medfun bulunanlardan üçüdür.

\section{TÜRBENIN BANİSI CAFER PAȘA'NIN HAYATI}

Enderun'dan yetişerek Silâhdâr-1 Şehriyârî olmuştur. Sokullu Mehmed Paşa döneminde II. Selim'in tahta çıkışında başkapıcı, sonra Yeniçeri Ağası oldu. Sokullu Mehmed Paşa, Cafer Ağa'yı kendine damat eylemiştir. 1568-1569 İstanbul yangınında, ağalıktan azledildiyse de ardından Rumeli Beylerbeyi, daha sonra vezirlikle kubbenişin oldu. Eşi, vefatında hamileydi ve sonrasında ikiz çocuk doğurdu. Evlatlarına Mehmed ve Cafer isimleri verildi. Gayet vakur kişiliğe sahipti (Mehmed Süreyya, (2), 1996: 381).

Hadîkatü'l-Cevâmi'nin, "Kızıl Mescid der-kurb-1 Cafer Paşa Medresesi” başlığı altındaki ilgili bölümde yazılanları günümüze uyarlayarak şöyle özetleyebiliriz: “... Kızıl Mescid yakınında bulunan türbede Cafer Paşa gömülüdür. Burada, adı geçen paşanın, medresesi ile Halvetiyye Tarîkatı'na ait zaviyesi vardır. 937 (1530-1531) tarihinde Sultan Süleyman'ın silâhdârlığından sonra Yeniçeri Ağası olmuştur. Sonrasında üç tuğ ihsan olunmuştur. Yakınlarıla beraber söz konusu türbede gömülüdürler. Tüm hayır eserleri hâlen haraptır. Peçevî Tarihi'nde, merhum Sultan Süleyman'ın son savaşı olan Zigetvar Fethi'nde silâhdârlık görevini yürüten Cafer Paşa'nın yazısının, padişahın yazısına çok benzemesi nedeniyle, padişahın hastalığında ve vefatından sonra gizli olarak sadrazam emriyle gerekli yazıları yazdığı nakledilmektedir. Vezîriâzamın rızasını kazandığından önce kapıcıbaşı, sonra yeniçeri ağası ve kendilerinin damadı olmuştur. II. Selim döneminde, İstanbul'da meydana gelen büyük yangında, yeniçerilerin özen göstermemeleri nedeniyle azledilmiştir. Sonra yine kayınpederi şehit Mehmed Paşa (Sokullu) himmetiyle Rumeli Beylerbeyi ve ardından vezirlik verilmiştir. Gayet vakur kişiliğe sahip Cafer Paşa, III. Murad döneminde 995 tarihinde vefat etmiş ve adı geçen türbeye defnedilmiştir. Allah rahmet eylesin" (Ayvansarâyî, 1314:278-279).

Mezar taşı kitabesinde Sultan Süleyman, Selim (II) ve Murad Han (III) dönemlerini yaşadığı, ancak Sultan Murad döneminde hakkıyla muradına eremediği ve 995 / 1587 tarihinde vefat ettiği yazılidır.

\section{TEKKE/MEDRESE}

Külliyenin doğu kesiminde yer alan tekke/medrese binası, " $u$ " şeklinde bir kütle görünümündedir (Şek. 6). Yapıya, türbenin kuzeyindeki girişten geçilen dar koridor aracilığıyla 
geçilmektedir. Dar koridorun ardından türbe ve medrese arasında kalan avluya, oradan da medresenin avlusuna ulaşılmaktadır (Foto. 14). "U” şekline benzer medresenin kuzey, güney ve doğu kanatlarında mekânlar varken, mekân bulunmayan batı kesimi avluya açılmıştır ve medreseye ulaştıran ana hattır (Foto. 15). Ana hattın medrese avlusuna yakın kesiminde, mescide varmadan az önce bir kuyu bulunmaktadır. Yenilenen zemin döşemeleri, türbeden medrese bölümüne alçalarak devam eder.

Toplamda birbirine komşu on iki mekân, medresenin tamamını oluşturmaktadır. Bunlardan güney kanadının batı ucundaki çıkıntılı kare mekân mescid, kuzey kanadının batı ucundaki küçük dikdörtgen mekân hela, arada kalan on mekân ise kısmen öğrenci, kısmen de derviş hücreleri olmalıdır. Odalardan güneydoğu ve kuzeydoğu köşelerdeki hücrelerin girişleri eğimli gelmektedir. Medrese mekânlarının cephelerinde iki sıra tuğla+bir sıra taş, mescid cephelerinde ise batı duvarında üç sıra tuğla+bir sıra taş, diğer cephelerde düzensiz almaşık duvar örgüsü hakimdir. Tüm cephelerin onarıldığı anlaşılmaktadır.

Güney, doğu ve kuzey kanatlarının avluya bakan kesimlerinde, muhtemelen tek sıralı revak uzanıyordu. Bugün duvarlardaki izlerin tamamen ortadan kalkması, kötü onarıma ve ahşapla yapılmasına bağlanabilir.

Güney kanadının batı ucundaki kare planlı hücre, muhtemelen medresenin ilk yapıldığ 1 dönemde mescid ve dershane olarak kullanıliyordu (Foto. 16). Tekke olarak kullanıldığ dönemlerde tevhidhane olarak da değerlendirildiği anlaşllıyor. Zikirlerin sönük olsa da özellikle son devirlerde mescitte yapıldığı belirtilmektedir (Turnalı-Yücel, 1991:180; Turnalı, 1992:555). Mekân, güney kanattaki diğer hücrelerden büyük olduğu için, cepheden avluya taşıntı yapmaktadır. Küçük boyutlu bir mekân olmasına rağmen, açılık ve nişlerle son derece hareketli bir görünüme kavuşturulmuştur. Kuzey cephesinde, ortaya giriş ve iki yanına alt sıraya birer, girişin üstüne denk gelen kesime bir pencere açılmıştır. Giriş aralığının üzeri basık kemerle geçilmiştir. Kemerin kilit taşına, altın yaldıza boyalı bir madalyon içinde çiçek motifi işlenmiştir. Giriş açıklı̆ının ahşaptan iki kanadı bulunmaktadır. Mescidin batı cephesine altta iki, bu iki pencereyi ortalayan üstte bir olmak üzere toplam üç pencere açılmıştır. Doğu cephesinde, medrese hücresinin bu cepheye yaslanması nedeniyle alt sıraya pencere açılmamış, sadece üst sırada bir pencere açıklığına yer verilmiştir. Güney cephesine ise üst sırada bir pencere açılmıştır. Girişin sövesi ve alınlığı mermerden, pencerelerinki küfeki taşındandır. Giriş ve alt sıra pencereleri taş söveli ve alınlıklı, üst sıra pencereleri tuğla kemerli ve alçı dışlıklıdır. Girişin ve alt sıra pencerelerinin tuğladan hafifletme kemerleri vardır.

Girişin tam karşı ekseninde yarım daire kesitli nişe, çeyrek küre şekilli kavsaraya sahip mihrap yer almaktadır (Foto. 17). Mihrabın iki yanıyla, doğu duvarında ikişer dolap nişi mevcuttur. Kare planlı harimin üzeri pandantif geçişli bir kubbeyle örtülmüştür. Harimin içi ve aşağıda tanıtılan medrese hücrelerinin içleri sıvanmış ve boyanmıştır. Kubbe, kurşun levhalarla kaplanmıştır. Mescidin saçak kotu, yanında devam eden hücrelerin saçak kotundan belirgin biçimde yüksektedir. Mescid/tevhidhane ile diğer hücrelerin kubbeleri üzerinde hilal ile sonlanan birer alem yükselmektedir.

Hücrelerin birer girişi ve yanında lokma demir parmaklıklı dikdörtgen pencereleri vardır (Foto. 18). Dikdörtgen taş söveli pencere ve kapıların tıpkı mescidde olduğu gibi tuğladan hafifletme kemeri vardır. Kapı ve pencerelerin üst hizalarına, sivri kemerli birer tepe penceresi açılmıştır. Sadece kuzeybatı köşedeki helanın üst sırasında pencere bulunmamaktadır. Hücrelerin içinde, birer ocak ve sayıları iki ile dört arasında değişen nişler görülmektedir (Foto. 19). Ocak ve nişlerin ahşap elemanları onarımlar sırasında takılmışlardır. Hücrelerin üzerleri pandantif geçişli birer kubbeyle örtülmüştür; ayrıca her birinin üzerinde, alt kesimi tuğladan, üst kesimi taştan koni şeklinde birer baca yükselmektedir. Kuzeydoğudaki hücre, "Çömlek ve Seramik Atölyesi", bu 
hücrenin batı bitişiğinde kalan diğer hücre "Ahşap Oyma Atölyesi" olarak kullanılmaktadır. Ancak yapıdaki incelemelerimiz esnasında (11 Haziran 2020), Kültür Sanat Merkezindeki faaliyetlerin geçici surette durdurulduğunu öğrendik.

Medresede herhangi bir kitabe bulunmamaktadır. Tekke kullanımına yönelik olarak, türbeyle aynı tarihte veya az önce yapıldığını düşünmek mümkündür.

\section{TARTIŞMA, SONUÇ ve ÖNERILLER}

Tasavvuf yapılarının en çok adlandırılan, zaviyelere göre daha teşkilatlı sayılabilecek binalar olan tekkelerin önemli merkezlerinden biri de Eyüpsultan olmuştur. Kuruluş tarihlerine göre bugünlere ulaşabilmiş 15. yüzyılda iki, 16. yüzyılda on üç, 17. yüzyılda üç, 18. yüzyılda on üç, 19. yüzyılda yedi olmak üzere otuz sekiz Eyüp tekkesi bilinmektedir. Yaklaşı bir bu kadar da günümüze ulaşamayan tekkenin varlığı bildirilmektedir (Çetin, 2012:431-441, 477-478).

Doğuda medrese, batıda türbeyle birlikte tasarlanıp uygulanan Cafer Paşa Külliyesi, zaman içinde kullanım değişikliği göstermiştir. Medresenin ne zaman yapıldığı kesin olarak bilinmese de türbenin yapıldığı 1585 yılına yakın bir tarihte inşa edilmiş olsa gerektir. Türbenin banisi, mezarının da içinde yer aldığı Cafer Paşa'dır. Osmanlı döneminde zamanla yükselen, aynı zamanda Sokullu Mehmed Paşa'nın damadı olan Cafer Paşa, türbenin tamamlanışından iki yıl sonra 1587 ' de hayata gözlerini yummuştur.

Külliyenin büyük yapısı olması nedeniyle öncelikle dikkat çeken medrese ya da diğer adıyla tekke üzerinde durmak gerekirse bu bina, avlu ve avlunun üç yanına ters " $u$ " şeklinde sıralanmış hücreleriyle dikkat çekmektedir. Başlangıçta, öğrencilerin barınması için yapılan 10 (on) hücrenin, binanın aynı zamanda tekke olarak kullanılmasından ötürü, derviş hücreleri ya da odaları olarak da kullanıldığını düşünmek mümkündür. Medrese/tekke bloğunda, güney kanadın batı ucundaki dikdörtgen mekân, mescid, tevhidhane ve dershane mekânları olarak kullanılmış olsa gerektir. Medrese ve tekke kullanımı birlikte düşünüldüğünde, dershane hücresinin daha sonradan tevhidhane olarak da değerlendirildiği, tıpkı medrese sürecinde olduğu gibi tekke döneminde de yine mescid olarak kullanıldığı pekâlâ düşünülebilir. Şeyh Vefa (1476) ve Piyale Paşa (1573) külliyeleri bu anlamda benzerlik gösterirler. Açık avlu-medrese hücresi-dershane-mescid ilişkisi, sosyal yapı olarak medrese, tarikat yapısı olarak tekke ve zaviyelerde karşılaşılan ortak kullanım mekânlarıdır.

Plan tipi farklılık göstermekle birlikte, avlu etrafında sıralanan öğrenci hücreleri, ana eyvan olarak bilinen dershane hücresi gibi mekânları barındıran binaların 12-13. yy. Anadolu Selçuklu medreselerinden beri kullanıldığı bilindiğine göre, bu kurumların Selçuklu, Beylikler ve Osmanlı dönemlerinde geçirdiği değişim de kendiliğinden ortaya çıkmaktadır. Üzeri açık ya da kapalı avluya sahip Selçuklu medresesiyle atılan tohum, sonraları filizlenmiş ve Osmanlı döneminde çiçeklenmiştir. Tabi medeniyetlere göre farklılaşan değişim, hiçbir zaman göz ardı edilmemeli, farklılıklar en azından ana hatlarıyla vurgulanmalıdır. Mesela, Selçuklu uygarlı̆̆ında girişin tam karşısına yerleştirilen ana eyvan, Cafer Paşa Medresesi'nde, öğrenci hücresine eklemlenmiştir. Medrese cami ikilisinin bir arada sunularak kaynaştırıldığ ${ }_{1}$ Osmanlı döneminde, cami genellikle ana akstadır. İbadet mekânı, Cafer Paşa örneğinde tali bir işlev yüklenmiş mescit tarzı kimliğiyle karşımızdadır. Aşağıda, plan ve mekân konumlanmasının, Cafer Paşa Tekkesi'nde görülenden farklı örnekleri olan eserler kısaca tanıtılacaktır. Buradaki amaç, plan gelişiminin nasıl çeşitlendiği ve geçirdiği farklılıkları vurgulamaktır. Şüphesiz çok sayıda örnek mevcuttur, ancak burada sadece hatırlatma bâbında birkaç örnek vermekle yetinilecektir.

Cami-medrese kaynaşımı gösteren ve ortak avluyu kullanan Anadolu örneklerinin kökeni 13. yy. Selçuklu dönemine kadar inmektedir. Bunun en çarpıcı örneklerinden birisi 1249-1250 tarihli 
Kayseri Hacı Kılıç Camii ve Medresesi'dir (Öney, 1966:382'den sonra gelen çizim 1, Katoğlu, 1967:338' den sonra gelen plan 2). Tabi burada, Cafer Paşa örneğinden farklı olarak kapalı form gösteren planlama görülür. Bu kapalı form Osmanlı öncesi Anadolu mimarisinde karşılaşılan bir formdur. Beylikler döneminden itibaren avlu genişlemeye ve açık ya da serbest form göstermeye başlar. Balat İlyas Bey Külliyesi'ne ait cami-medrese ikilisi (1404), Osmanlı dönemine geçişin önemli temsilcisidir (Durukan, 1998:28, Demiralp-Çakmak, 2011:201, şek. 2). Artık burada camiye bağlanan ve avluyu üç yönden kuşatan düzenlemeyle, Osmanlı dönemi uygulamalarına yaklaşılmıştır. Osmanlı dönemine gelindiğinde, Sinan dönemi dâhil bazı örneklerde temsilcileri bulunmaktadır. Bunlardan İstanbul/Beşiktaş'taki Sinan Paşa Camii (1555) (Aslanapa, 1986:220), İstanbul/Edirnekapı, Mihrimah Sultan Camii (1558) (Aslanapa, 1986:222), İstanbul/Kadırga'daki Sokullu Camii (1571-1572) (Aslanapa, 1986:273), İstanbul/Üsküdar Şemsi Paşa Camii (1580) (Aslanapa, 1986:292) ile müşterek avluyu kullanan medreseler verilebilir. Elbette hiçbir planın birbirinin aynısı olmadığı, cami ile medresenin birbirine göre konumlarının birbirinden farklı olduğu söylenmelidir. Buradaki ana vurgumuz ve genel çerçeve, prensipte cami ve medresenin ortak bir avlu etrafında toplandığı ve bu kombinasyonun Selçuklu döneminden beri değişerek geldiğidir. Cafer Paşa Tekkesi'nde görülen mescit-medrese ve ortak avlu kullanımı, yukarıda açıklanmaya çalışıldığı gibi farklı ve mütevazı tarzıyla karşımızdadır.

Eyüp'te, avluya açılan derviş (medrese) odaları, türbe (dershane), tevhidhane, mescid ve hazire gibi üniteleri olan Şeyh Murad Efendi Tekkesi (1715), işlev ve ana fikir açısından Cafer Paşa Tekkesi'nden farklı değildir. Hazire, Cafer Paşa Tekkesi'nde türbe içine alınmışken, Murad Efendi Tekkesi'nde bağımsız iki ayrı parsele dağıtılmıştır. Ayrıca mescidin, külliyenin güneydoğu köşesine alındığı gözlenmektedir (Tanman, 1994b:514-516; Erdem, 1998:216-225).

Külliyenin diğer bileşeni olan türbeye gelince, öncelikle ana değişimin plandan çok içindeki mezar şahideleriyle ilgili olduğunu hatırlatalım. Bani Cafer Paşa'nın 1587 tarihli mezar taşı en eskilerinden olmakla birlikte, bina, daha sonra tekkeyi canlandıran Halvetî, Kadirî, Sa' dî şeyhleri ve yakınlarının sonsuzluğa uğurlandığı istirahatgâha dönüşmüştür. Dıştan bakıldığında dikdörtgen kütle olarak görünen ancak içine girildiğinde yatanların kimliklerine izafetle sağlanan mistik hava, türbenin kutsallığına yapılacak vurgudur. Bugün görülemese de vaktiyle ahşap tavan ve çatıyla örtülü olduğu da vurguya muhtaçtır.

Klasik Osmanlı külliyesinin, bezemeden yoksun bırakılması, muhtemelen şekilden çok öze yönelen tarikat ruhuna addedilmelidir. 300 yılı aşkın bir süredir tarikat merkezi gibi canlandırılan tekkenin emanet olarak geldiği bugünlerde, onarılarak kültür ve sanat merkezi işlevi kazandırılacak olması, ona saygı duyulduğunun açı göstergesidir.

\section{Proje Uygulamasına Dair Öneriler}

Bugün Eyüp Sultan Belediyesi tarafından hayata geçirilmek istenen Sergi Projesi'nin, Cafer Paşa Külliyesi bünyesinde uygulamaya konulmak istenmesi, bu araştırma yazısının kaleme alınma gerekçesini oluşturmuştur. 2863 Sayılı Kültür ve Tabiat Varlıklarını Koruma Kanunu ve bağlı mevzuat hükümleri birlikte değerlendirildiğinde, henüz uygulamaya geçmemiş projenin, korumacılık anlayışına uygun, tarihi esere saygı duyan bir uygulama görüntüsü verdiği ifade edilebilir. Bu yönüyle "tarihi esere saygı duyan, onu ezmeyen, ona en az müdahalede bulunan, eski ve yeninin başarılı bir şekilde kaynaştığı” proje görüntüsü vermektedir. Uygulamanın her aşamasında tarihi eser korumacılığının istisnasız olarak hayata geçirilmesi, uygulamayı yapacaklar için rehber niteliği taşımaktadır.

Yakın zamana kadar "Cafer Paşa Medresesi Kültür Sanat Merkezi" olarak hizmet veren külliyenin, yapılacak yeni uygulamayla modern sunuma sahne olacağı anlaşılmaktadır. Bunun 
için külliye sınırlarında kalan açık alanlar ile türbe ve medrese-tekkenin hücreleri değerlendirilecektir.

Ancak gerek uygulama öncesinde gerekse uygulama sırasında dikkat edilmesi gereken bazı hususlara aşağıda dikkat çekilmiştir.

-Türbenin güneyindeki yamuk planlı arsada yapılmak istenen sergi alanına girişin, aynı zamanda türbenin güney girişine de geçit veren kapıdan sağlanacağı anlaşılmaktadır (Şek. 7). Buradaki sergi alanı çelik konstrüksiyonlu, cam doğramalı ve düz değil de eğimli tavanlı mekândan oluşacaktır (Şek. 8). Söz konusu kuruluşun giriş kapısına yük bindirmemeye, eğer zorunlu olacaksa bu yükün optimum düzeyde olmasına özen gösterilmelidir.

-Türbenin güney kesiminde yapılacak sergi alanını belirleyen mekânın çatısı, türbe duvarının gabarisini geçmemelidir.

-Söz konusu sergi alanının iç kesiminde, sergi objelerinin sabitleneceği küçük duvarların yönü avlu güney duvarına paralel olabileceği gibi dikey olarak da konumlandırılabilir. Bu tamamen tercihe bağlıdır. Buna dair örnek çizim şekil 9'da gösterilmiştir.

-Medrese-tekkenin iç avlusunun üzerini örtecek olan cam doğramalı çelik konstrüksiyonun mescid-tevhidhane ve diğer hücrelerin duvarlarına yaslanmamasına, zorunlu olmadıkça duvarlara delik açılmamasına asgari özen gösterilmelidir (Şek. 10-11). Proje görsellerinden anlaşıldığı kadarıyla gerek çelik ayaklar gerekse de çatının çelik profilleri beden duvarlarına temas etmemekte ve yük bindirmemektedir.

-Medrese-tekkenin iç avlusunun üzerini örten çelik profil ve cam doğramalı imalatın uygulanmasında gösterilmesi beklenen titizlik ve hassasiyet, iç avlunun giriş kesimine (mescid giriş eksenine) yapılması planlanan hediyelik eşya biriminde de gösterilmelidir.

-Türbede olduğu gibi, medrese avlusunda da sergi objelerinin sabitleneceği demontable duvar parçalarının yönü tercihe bağlıdır (Örnek için bkz. Şek. 12).

-Kafeterya olarak tasarrufta bulunulan mescid-tevhidhanenin, burada kullanılacak olan masa ve sandalye gibi tefrişatın duvarlara temas ettirilmemesine, çeşitli gerekçelere bağlı olarak duvarlara delik, oyuk açılmamasına dikkat edilmelidir. Mihrap ile iki yanındaki ve doğudaki toplamda beş nişin eşya gözü gibi kullanılmamasına özen gösterilmelidir (Fotoğraf 17).

-Derslik olarak projelendirilen mescid-tevhidhanenin solundaki (doğu) üç hücreye yerleştirilecek masa, tahta ve sıra gibi eşyaların sabitlenmemeleri, duvarlara temas ettirilmemeleri esas alınmalıdır (Şek. 12).

-Medresenin doğu ve kuzey kanatlarındaki geri kalan yedi hücresi, sergi odaları olarak değerlendirileceğinden sergilenecek objelerin, kolay sökülebilir nesnelerde yer alması ve bu nesnelerin de odalar içindeki duvar ve dolap nişlerine zarar vermeyecek şekilde konumlandırılmaları önem taşımaktadır.

-Yeni yapılacak sergi alanlarının çatısı, yağmur ve kar sularının birikmesini önleyecek şekilde tasarlanmalı, bu yolla tarihi esere verilecek olası zararın da önüne geçilmelidir. Aynı şekilde, yapılacak yeni imalatın yalıtım sorunu iyi planlanmalıdır.

-Medrese avlusunun üzerini örten çatının, avludaki ağaçların kesilmesini önleyecek şekilde tasarlanması gereklidir.

-Sergi alanlarında, eğer ileride yapılacaksa, aydınlatma elemanlarının zemin, duvar ve tavanlara monte edilmesi işlemlerinde mekânlara en az müdahale yapacak seçenekler hayata geçirilmelidir. 
-Her ne kadar külliyenin dışında kalsa da projenin tamamlanmasıyla hayata geçirilecek tek bloklu tuvalet-mutfak mekânlarının gabarisi, külliye eserlerini ve ihata duvarının gabarisini geçmeyecek şekilde projelendirilmelidir.

-Projede dört alternatifli olarak sunulan sergi elemanlarının konumu ve nasıl yerleştirileceği hususu ilgili Koruma Bölge Kurulu tarafından alınacak kararla belirlenecektir.

\section{KAYNAKÇA}

Aslanapa, O. (1986). Osmanlı Devri Mimarisi, İstanbul: İnkılâp Kitabevi.

Ayvansarâyî. (Gurre-i Ramazan 1281). Hadîkatü'l-Cevâmi, 1, Matbaa-i Âmire.

Barışta, H. Ö. (2000). İstanbul-Eyüpsultan Cafer Paşa Türbesi Kazısı ve Bitkisel Bezemeli Mezar Taşları Üzerine, Tarihi, Kültürü ve Sanatıyla Eyüpsultan Sempozyumu, Tebliğler, 5-7 Mayıs 2000, C. 4, Eyüp Belediyesi Kültür Yayınları: 13. İstanbul. ss:252-277.

Çetin, A. (1981). İstanbul'daki Tekke, Zâviye ve Hânkahlar Hakkında 1199 (1784) Tarihli Önemli Bir Vesika, Vakıflar Dergisi, 13: 583-590.

Çetin, N. (2012). Eyüp Tekkeleri, Yayımlanmamış Doktora Tezi, T.C. Marmara Üniversitesi, İstanbul.

Demiralp, Y. ve Çakmak, Ş. (2011). Balat İlyas Bey Külliyesi 2007-2008 Kazı ve Temizlik Çalışmaları, Balat İlyas Bey Külliyesi, Tarih, Mimari, Restorasyon, (Editör) Tanman, B.-Elbirlik, L. K. (ss. 199-218).

Durukan, A. (1988). Balat İlyas Bey Camii, Ankara: Kültür ve Turizm Bakanlığı Yayınları.

Erdem, A. (1998). Eyüp Şeyh Murad Efendi Tekkesi Avlu Kapısı, Çeşme ve Şadırvan Restitüsyonu, Tarihi, Kültürü ve Sanatıyla II. Eyüpsultan Sempozyumu, Tebliğler, 8-10 Mayıs 1998. Eyüp Belediyesi Kültür Yayınları 9. İstanbul. ss:216-225.

Evliya Çelebi Mehmed Zıllı ibn Derviş. (1314). Evliya Çelebi Seyahatnamesi, C. 1, Dersaadet: İkdam Matbaası.

İsen, M. (1992). Beyânî, Türkiye Diyanet Vakfı İslam Ansiklopedisi, 6:32.

Katoğlu, M. (1967). XIII. Yüzyıl Anadolu Türk Mimarisinde Külliye, Belleten, 31, (123): 335-344.

Mehmed Süreyya, (1996). Sicill-i Osmanî Osmanlı Ünlüleri (Yay. Haz. Nuri Akbayar), 2 ve 4 İstanbul: Tarih Vakfı Yurt Yayınları.

Öney, G. (1966). Kayseri Hacı Kılıç Camii ve Medresesi, Belleten, 30(119): 377-390.

Tanman, M. B. (1990). İstanbul Tekkelerinin Mimari ve Süsleme Özellikleri, Tipoloji Denemeleri, Yayımlanmamış Doktora Tezi, T.C. İstanbul Üniversitesi.

Tanman, M. B. (1994a). Cafer Paşa Türbesi, Dünden Bugüne İstanbul Ansiklopedisi, 2: 367-369.

Tanman, M. B. (1994b). Murad Buharî Tekkesi, Dünden Bugüne İstanbul Ansiklopedisi, 5: 514-516.

Turnalı, A. B. ve Yücel, E. (1991). İstanbul'da Az Bilinen Bazı Tekkelerin Yerlerine Dair Bir Araştırma (II), Türk Dünyası Araştırmaları Dergisi, 70: 177-191.

Turnalı, A. B. (1992). Cafer Paşa Tekkesi, Türkiye Diyanet Vakfi İslam Ansiklopedisi, 6: 555. 


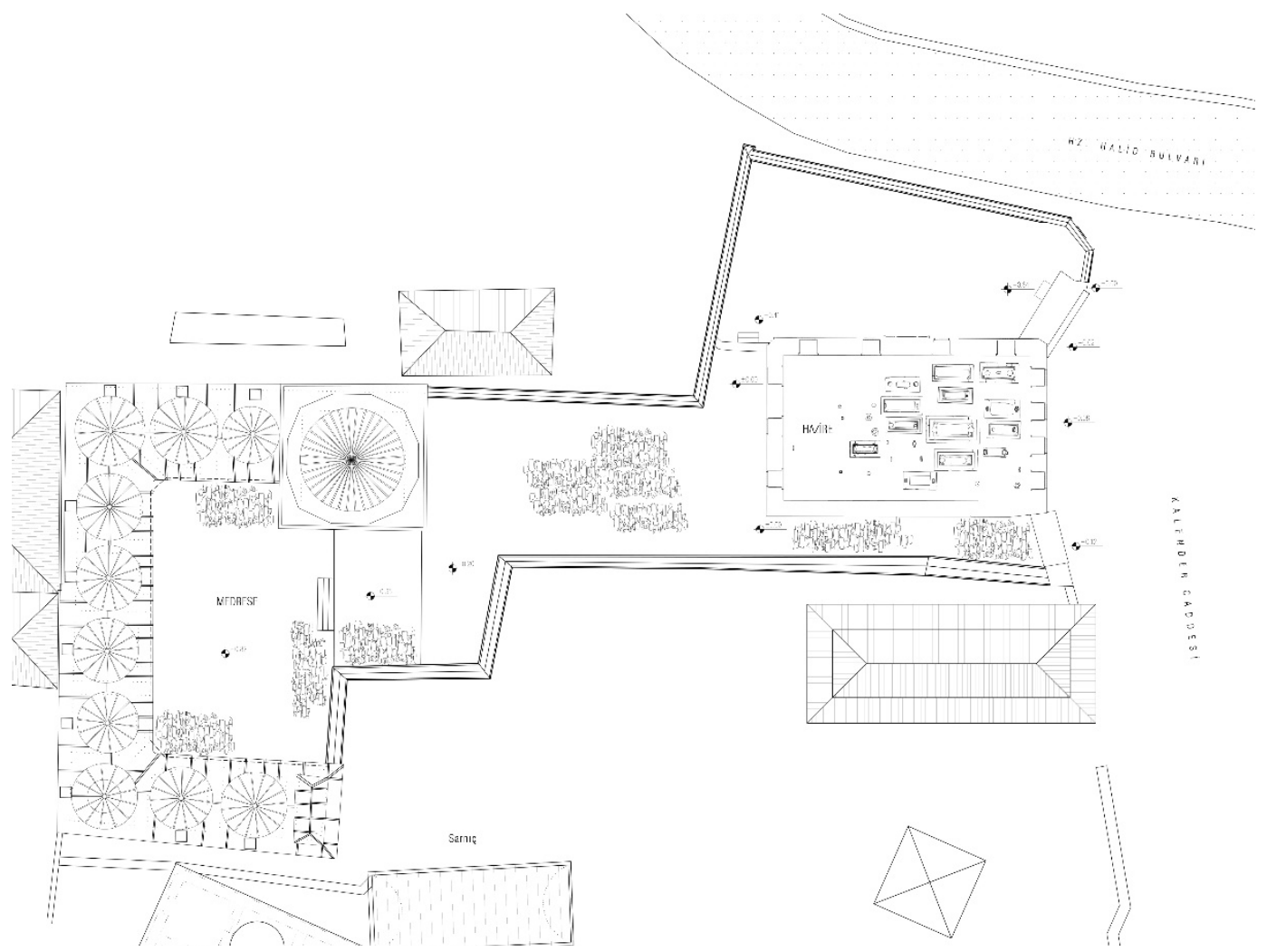

Şek. 1- Cafer Paşa Külliyesi, vaziyet planı (Ahmet Alataş Mimarlık)
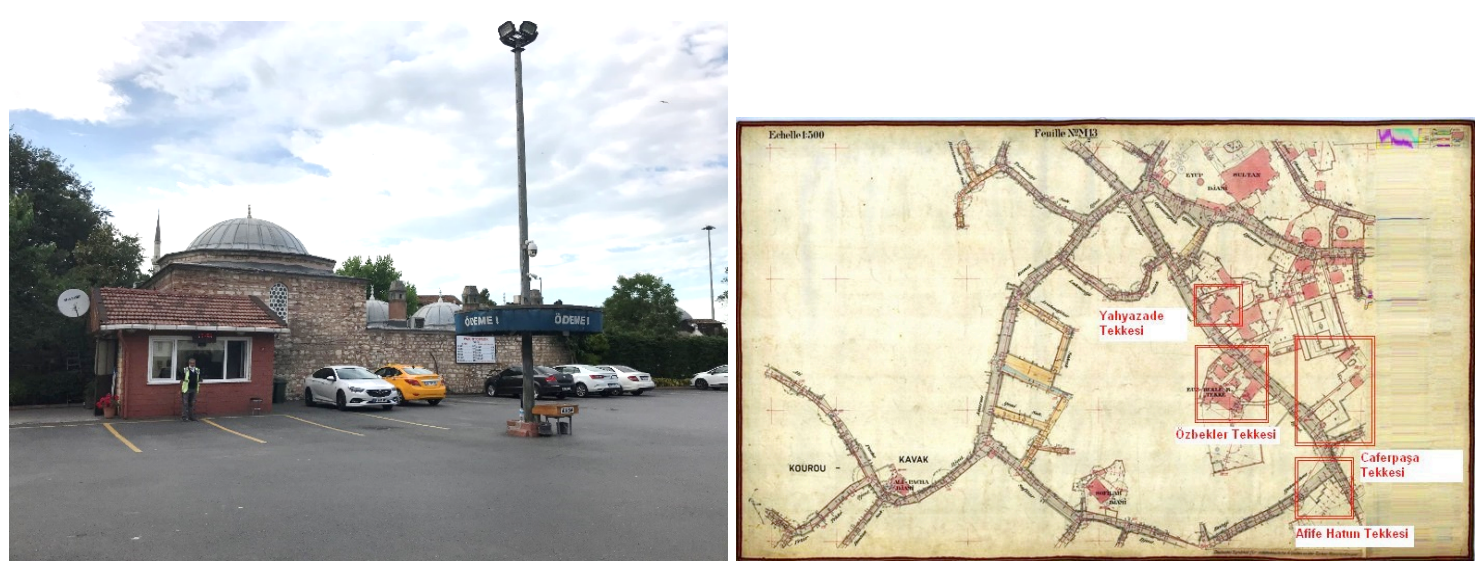

Foto 1. Cafer Paşa Külliyesi,

Şek 2. Alman Sendika Haritasında Afife Hatun, Güneyden Genel Görünüm. Cafer Paşa, Özbekler ve Yahyazade tekkeleri (Çetin 2012: 500, harita 12) 

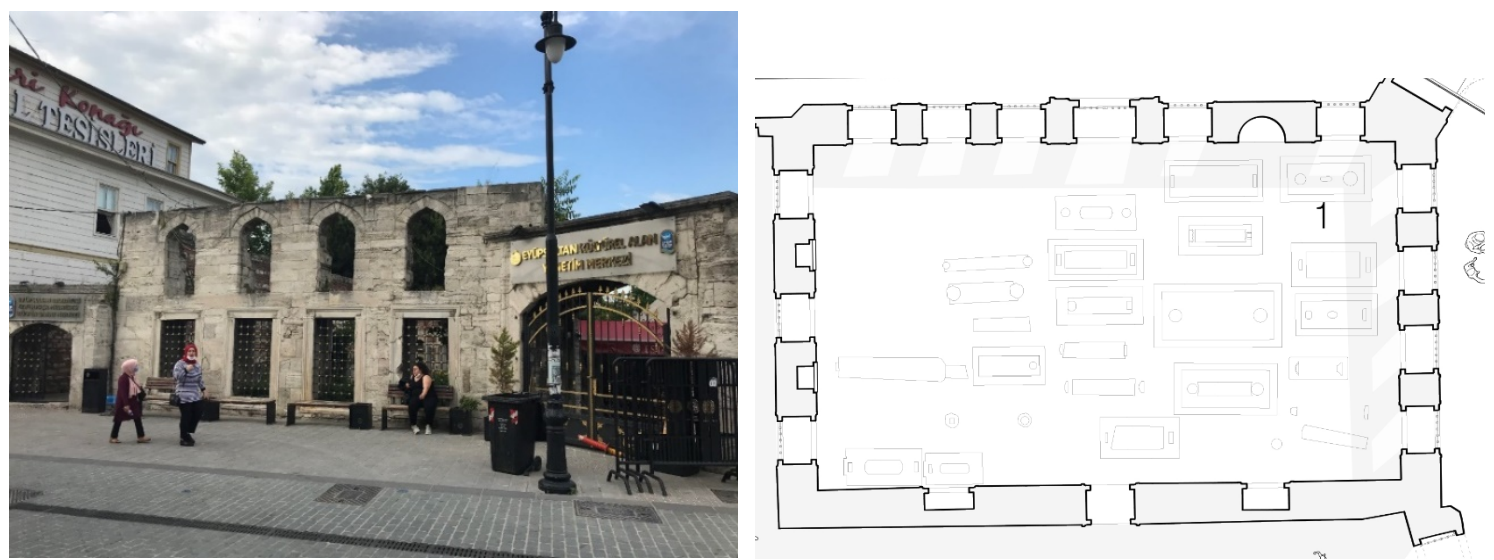

Foto 2. Külliyenin Batı Girişleri.

Şek 3. Türbenin Rölöve Planı (Ahmet Alataş Mimarlık).

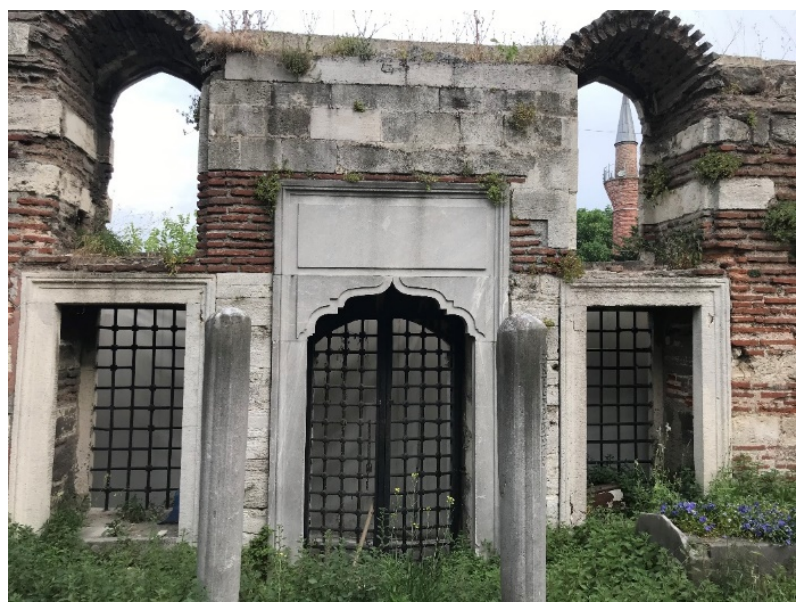

Foto 3. Türbe Güney Girişinin İçten Görünüşü.

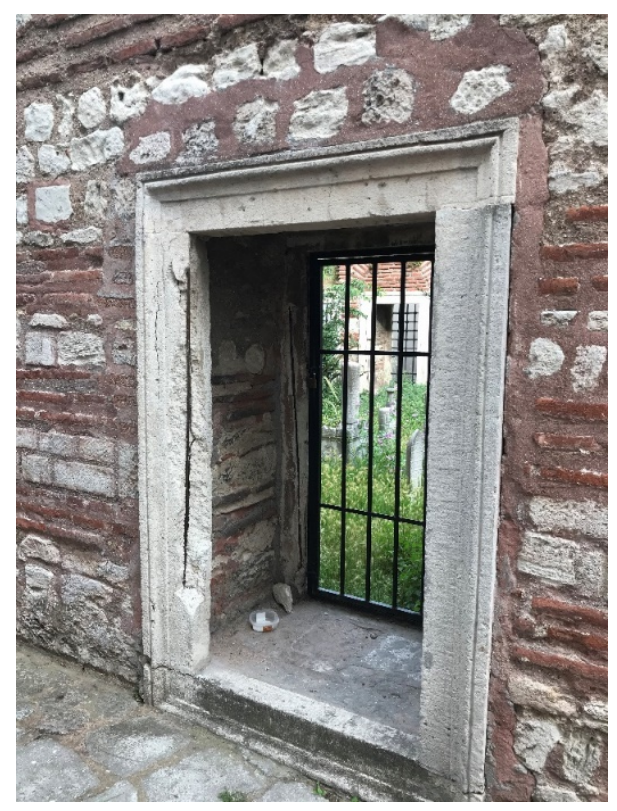

Foto 4. Türbenin Kuzeyindeki Pencere.

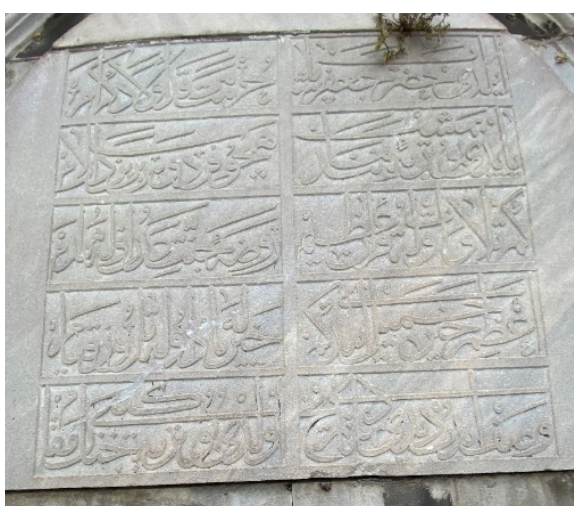

Foto 5. Türbe Kitabesi.

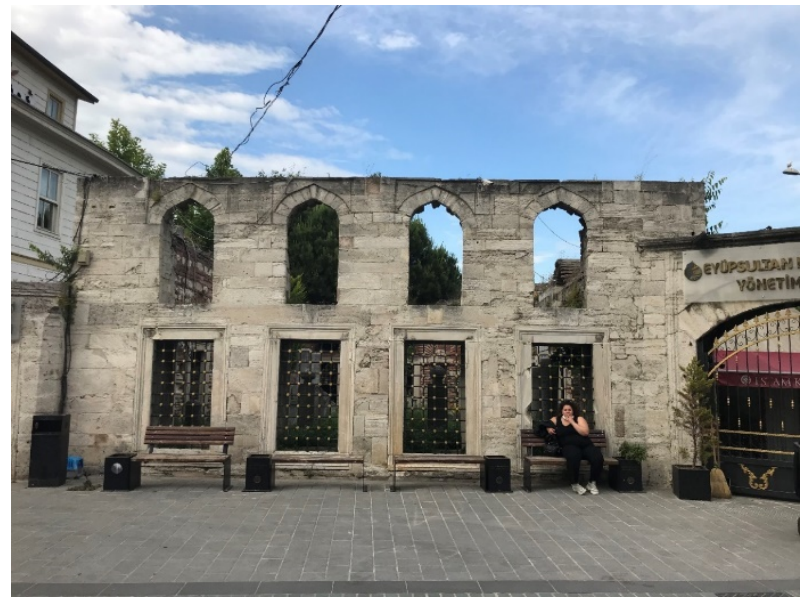

Foto 6. Türbenin Batı Cephesi. 

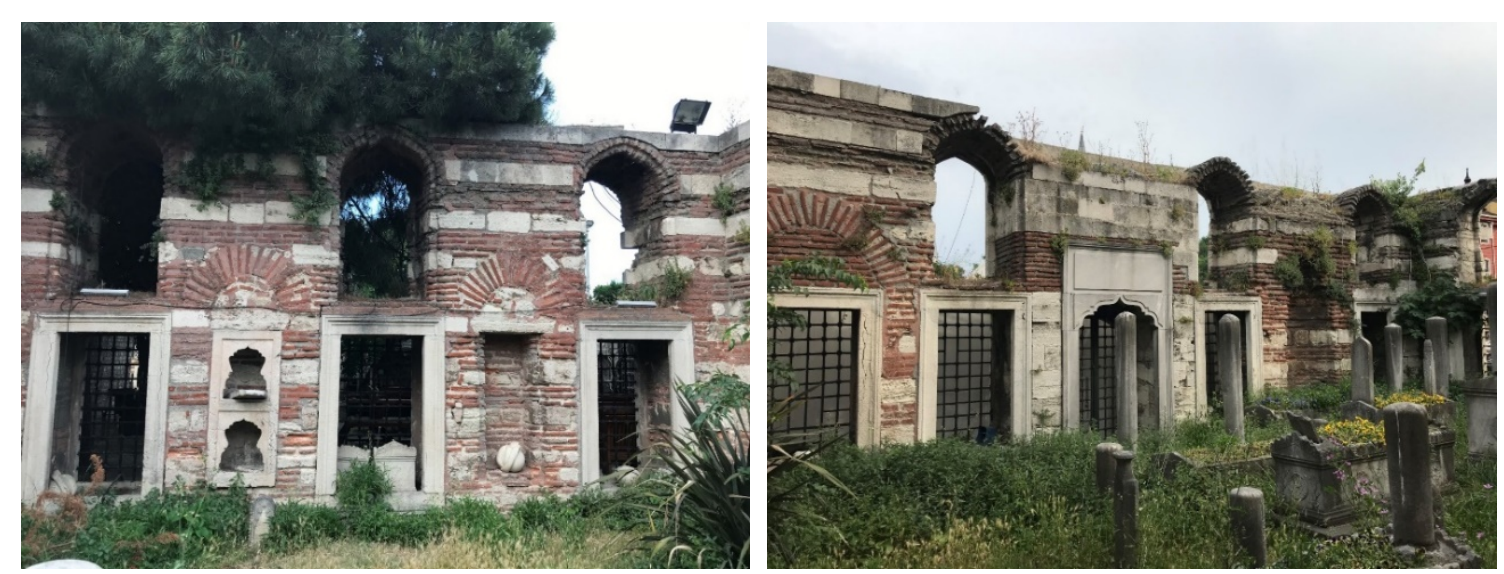

Foto 7. Türbe Batı Duvarı (İçten)

Foto 8. Türbe Güney Duvarı.

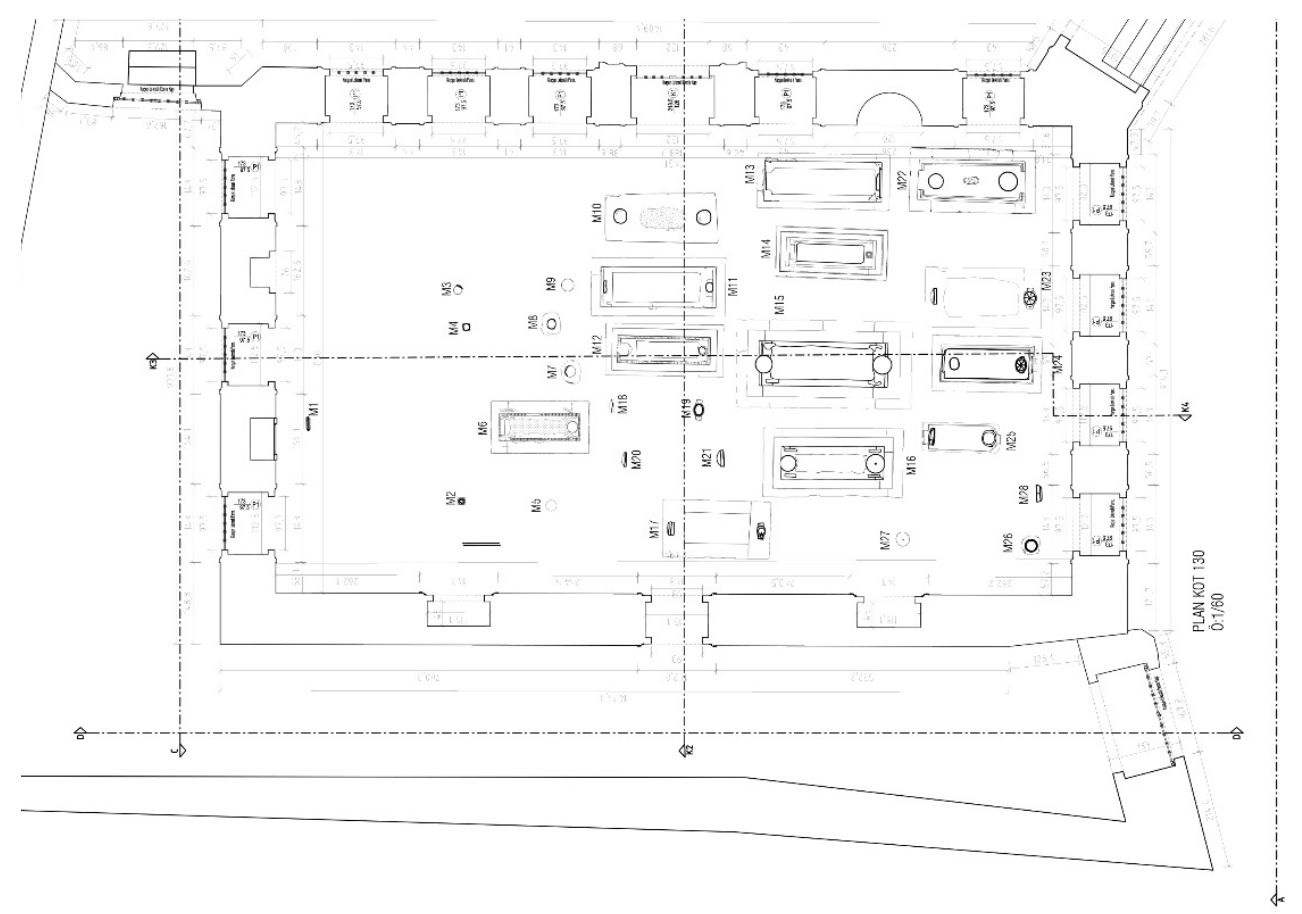

Şekil 4. Türbe İçindeki Mezarların Rölövesi (Ahmet Alataş Mimarlık). 


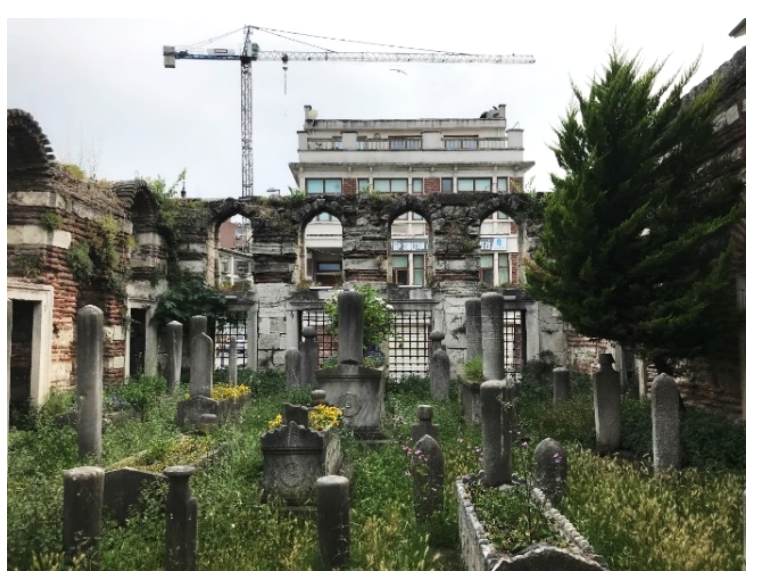

Foto 9. Türbe İçindeki Mezarlar.

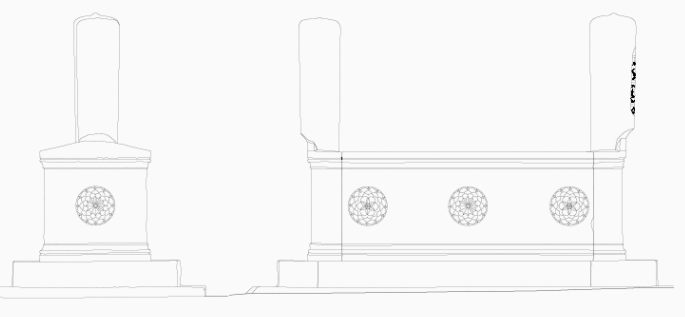

Şekil 5. Cafer Paşa Mezarının Çizimi (Ahmet Alataş Mimarlık).

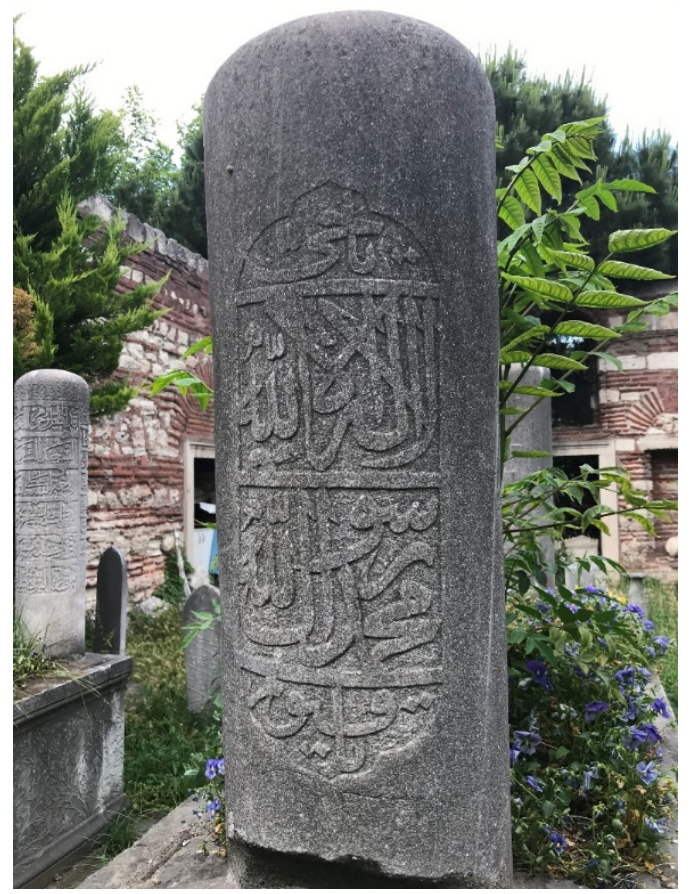

Foto 11. Cafer Paşa Mezarının Baş Şahidesi.

Foto 10. Cafer Paşa'nın Mezarı.

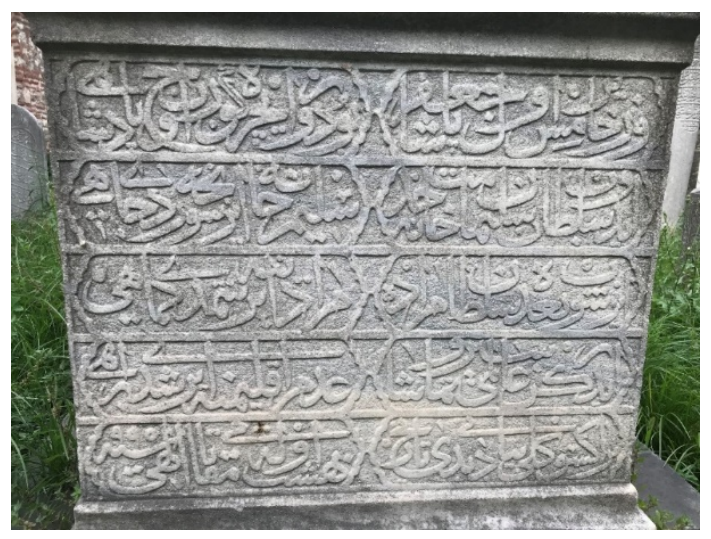

Foto 12. Cafer Paşa Mezarının Ön Yüzdeki Kitabesi. 


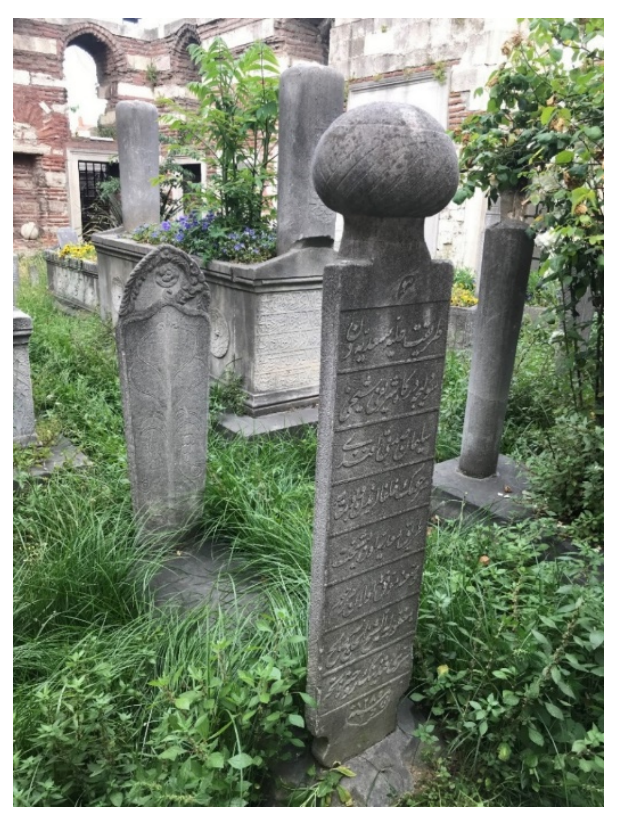

Foto 13. Salih Sırrı Efendi'nin Mezar Taşı.

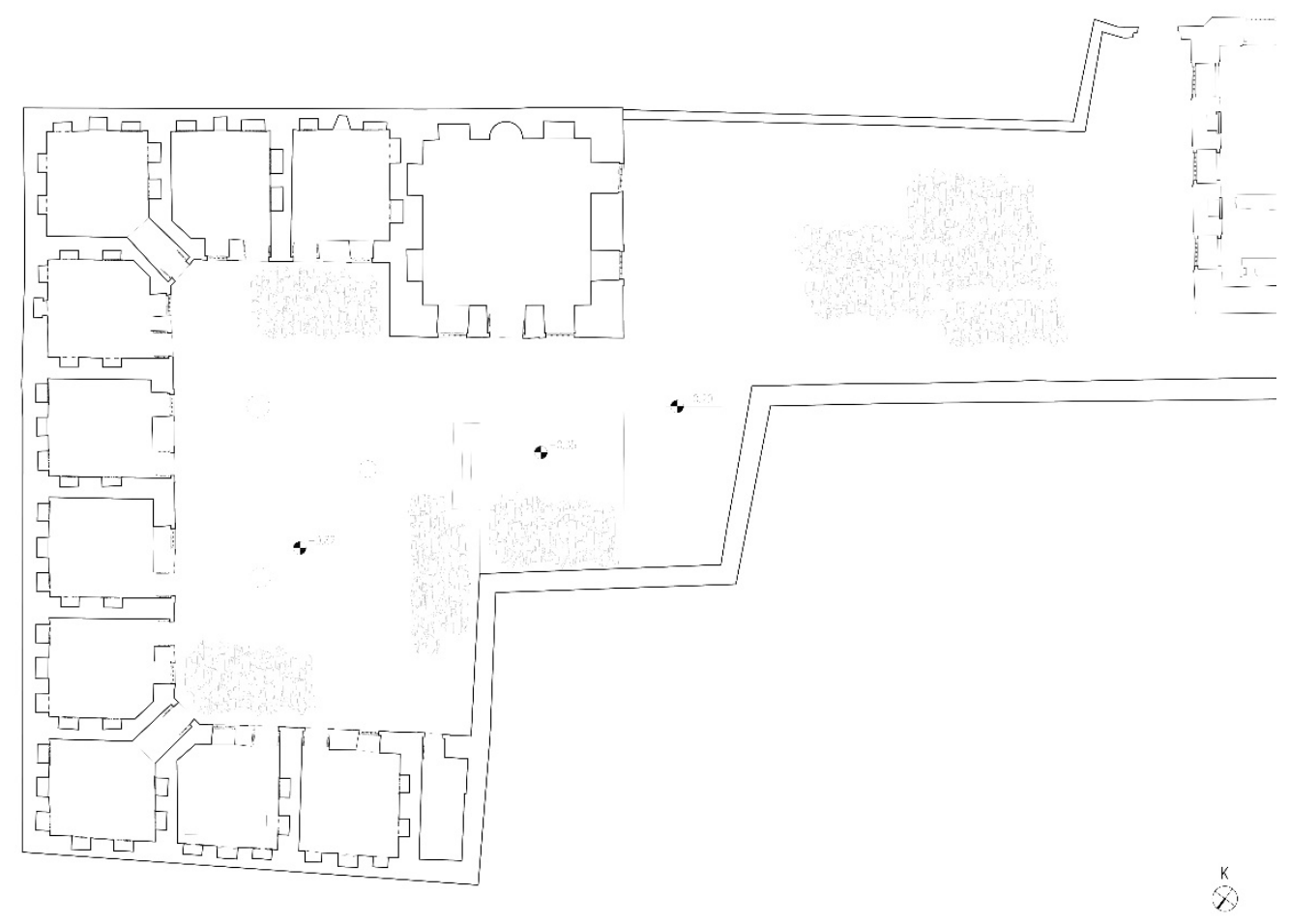

Şekil 6. Tekke/Medresenin Genel Planı (Ahmet Alataş Mimarlık). 


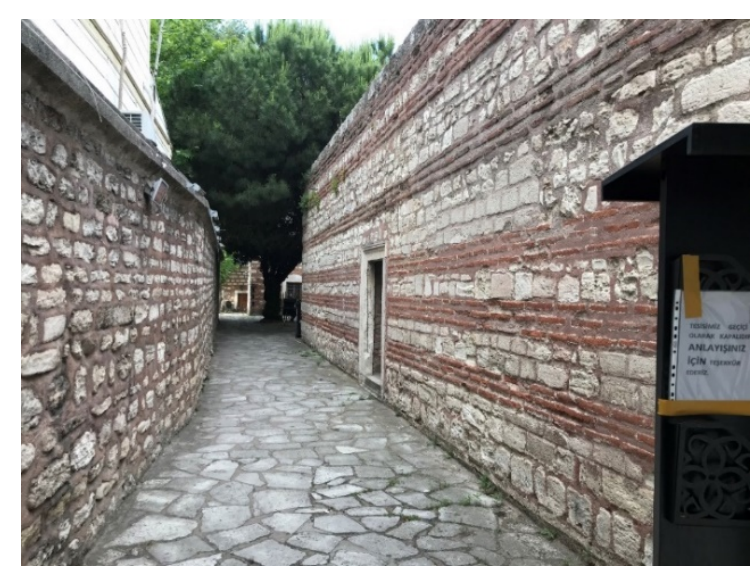

Foto 14. Türbenin Kuzeyindeki Koridor.

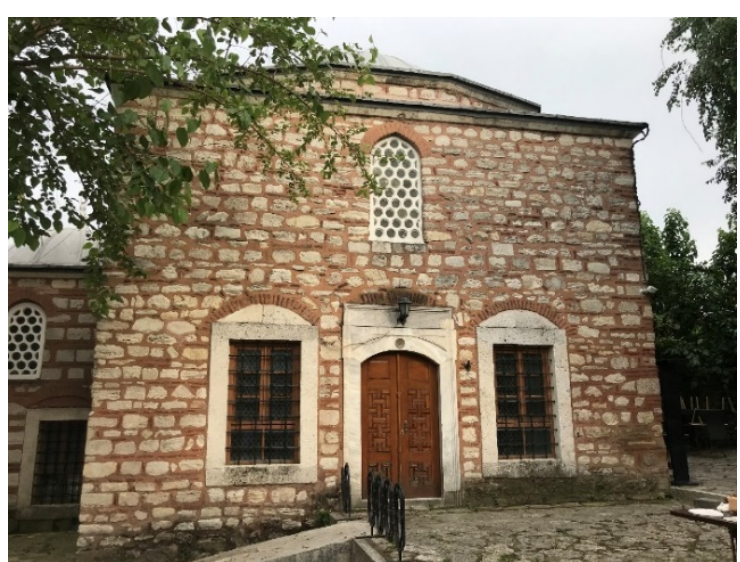

Foto 16. Mescidin Kuzey Cephesi.

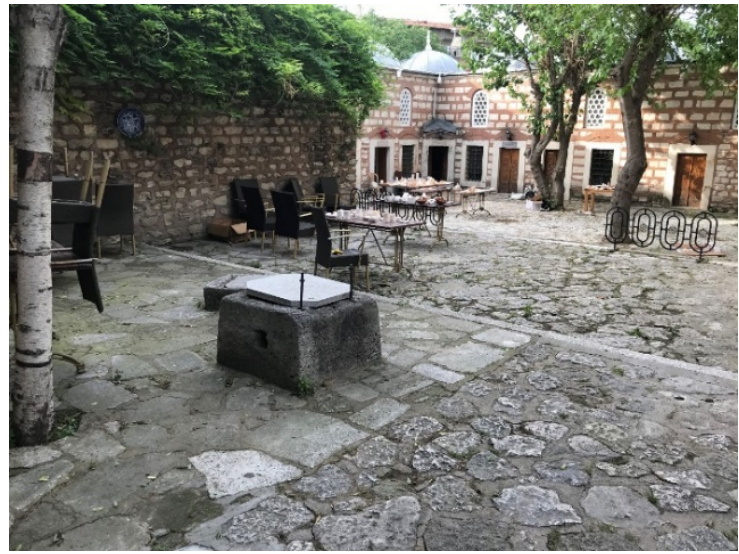

Foto 15. Tekkenin Kuzeydoğudan Görünüşü.

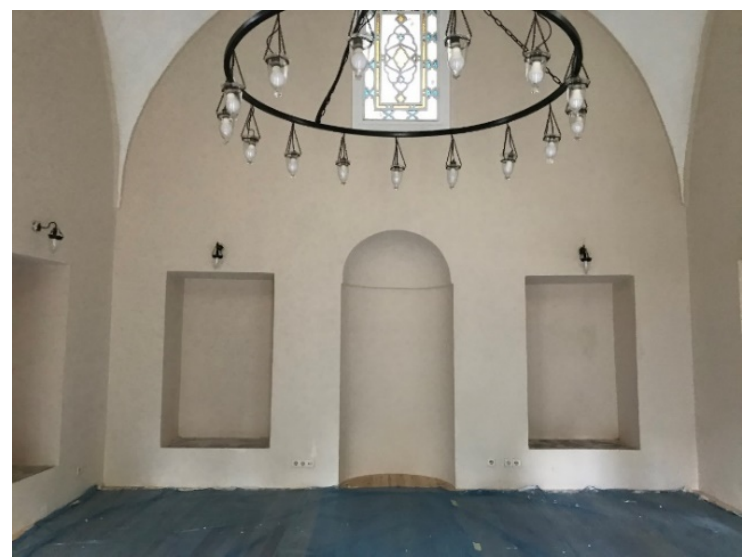

Foto 17. Harim Kıble Duvarı.

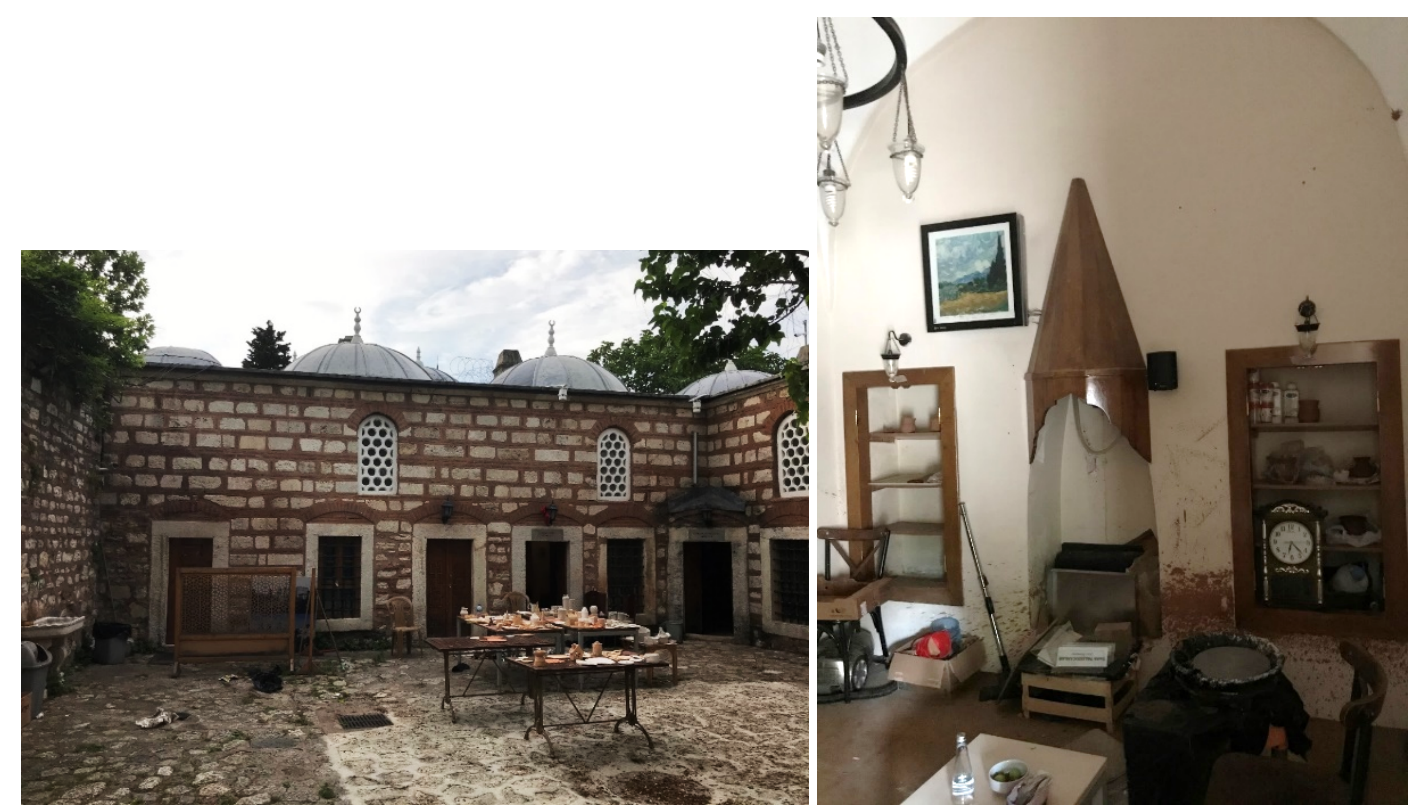

Foto 18. Medrese/Tekke Kuzey Duvarı.

Foto 19. Kuzeydoğu Köşedeki Medrese Hücresi. 

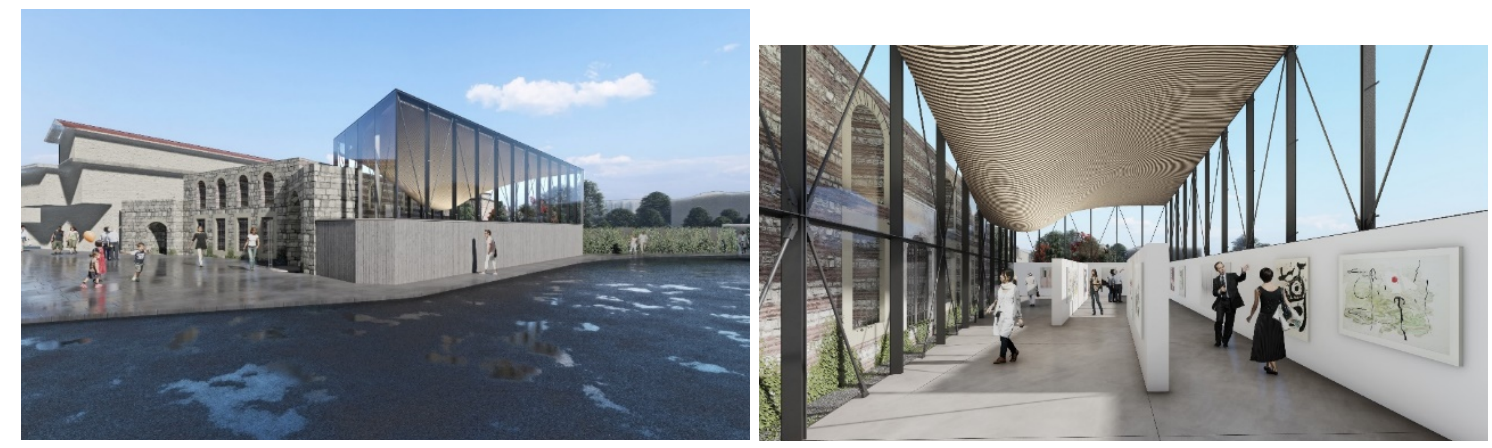

Şekil 7. Türbenin güney kesimine uygulanması Şekil 8. Türbenin güney kesimine uygulanması düşünülen sergi projesi (Ahmet Alataş Mimarlık) düşünülen sergi projesi

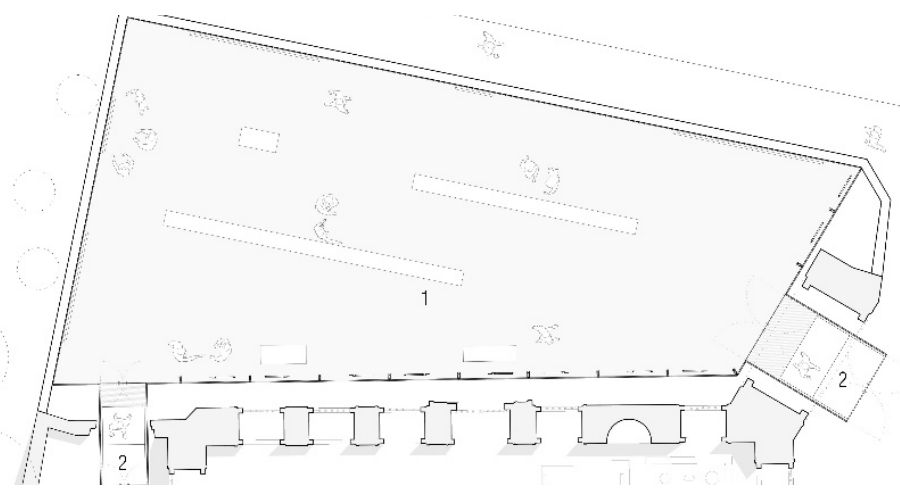

Şekil 9. Türbe Avlusunun Güney Kesimindeki Sergi Alanının İç Duvar Yerleşiminden Bir Örnek (Ahmet Alataş Mimarlık)

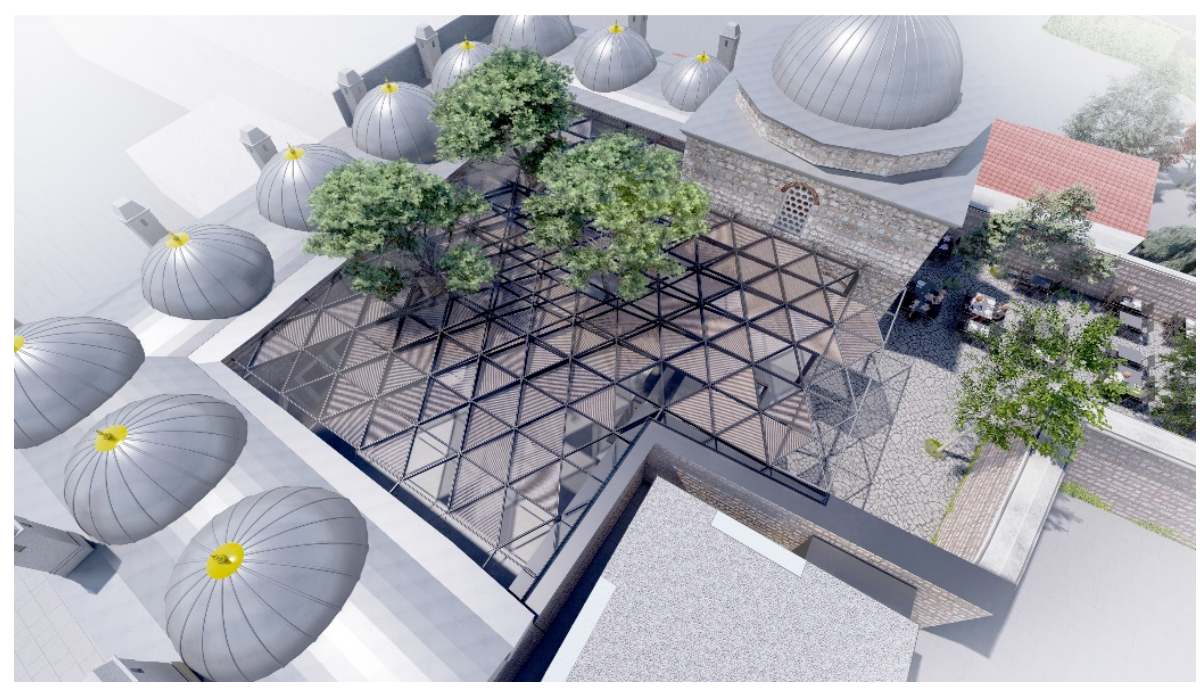

Şekil 10. Medrese Avlusunun Üzerini Örten Çatı Projesi (Ahmet Alataş Mimarlık) 


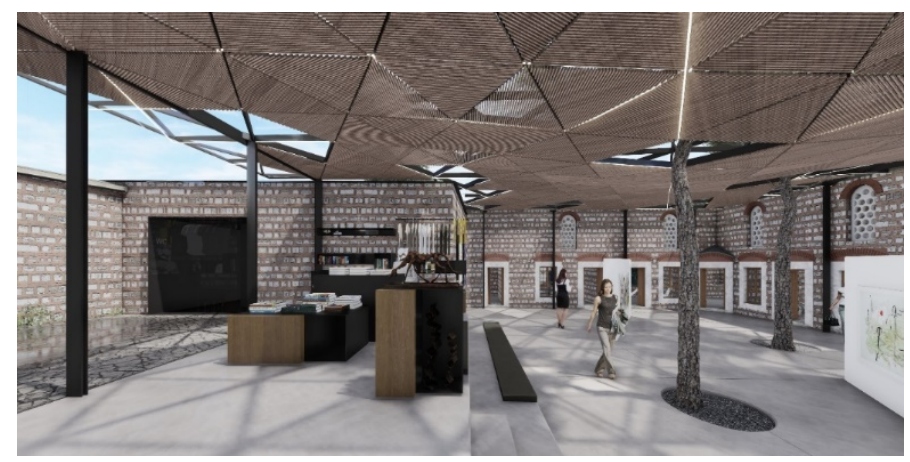

Şekil 11. Medrese Avlusunda Yapılması Planlanan Sergi Proje Önerisi (Ahmet Alataş Mimarlık)

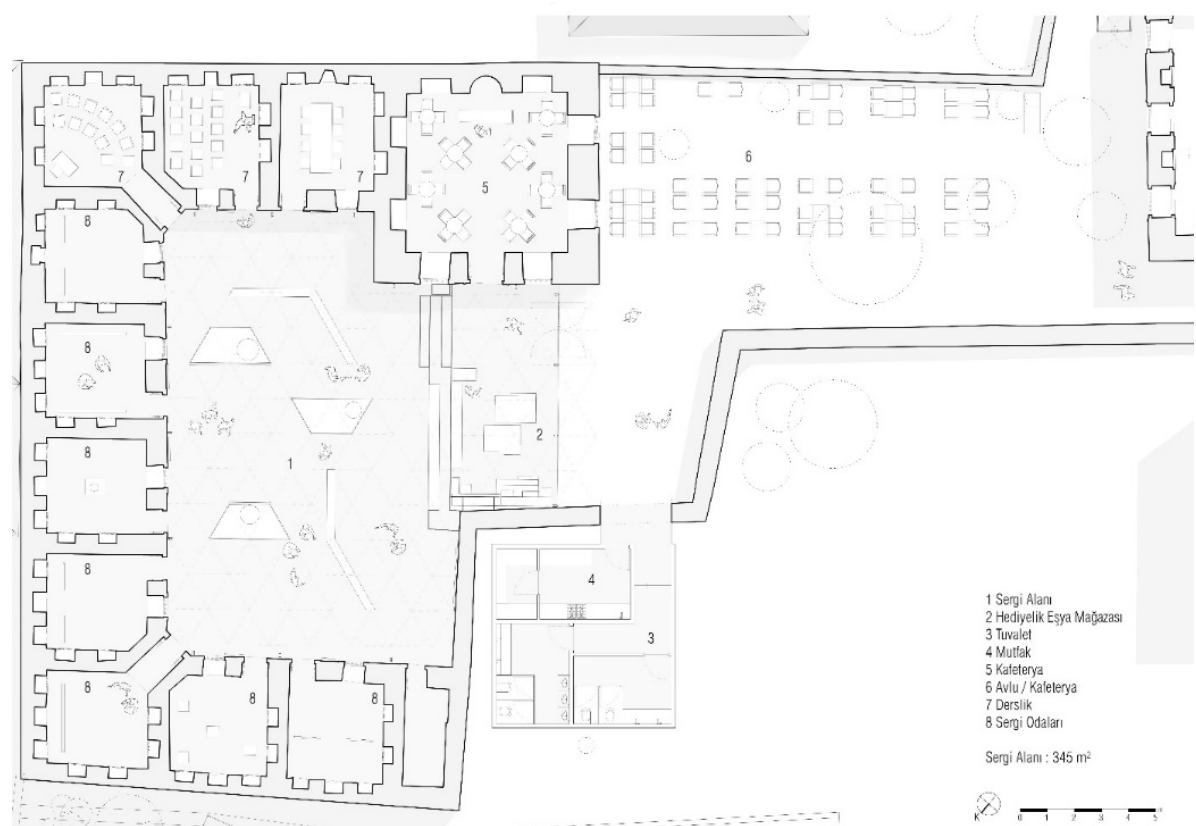

Şekil 12. Medrese Avlusunda Yapılması Planlanan Sergi Proje Önerisi (Ahmet Alataş Mimarlık) 